\title{
Mineralogy and Leachability of Natural Rocks-A Comparison to Electric Arc Furnace Slags
}

\author{
Daniel Vollprecht ${ }^{1, *} \mathbb{0}$, Max Berger ${ }^{2}$, Ingrid Altenburger-Junker ${ }^{1}$, Simone Neuhold ${ }^{1}$, \\ Klaus Philipp Sedlazeck ${ }^{1}$, Alexia Aldrian ${ }^{1}$, Joris J. Dijkstra ${ }^{3}{ }^{\circledR}$, André van Zomeren ${ }^{4}$ \\ and Johann G. Raith ${ }^{2}$ \\ 1 Montanuniversität Leoben, Chair of Waste Processing Technology and Waste Management, \\ Franz-Josef-Str. 18, 8700 Leoben, Austria \\ 2 Montanuniversität Leoben, Chair of Resource Mineralogy, Peter-Tunner-Str. 5, 8700 Leoben, Austria \\ 3 TNO Geological Survey of the Netherlands, Princetonlaan 6, 3584 CB Utrecht, The Netherlands \\ 4 ECN part of TNO, Westerduinweg 3, 1755 LE Petten, The Netherlands \\ * Correspondence: daniel.vollprecht@unileoben.ac.at; Tel.: +43-3842-402-5110
}

Received: 26 July 2019; Accepted: 16 August 2019; Published: 20 August 2019

Abstract: In waste management, recycled and industrial aggregates (e.g., electric arc furnace (EAF) slags) for construction applications have to fulfil the limit values with respect to the total and/or leachable contents of potentially environmentally problematic chemical elements (PEPE, e.g., $\mathrm{Cr}, \mathrm{Ni}$, $\mathrm{Cu}, \mathrm{Mo}, \mathrm{V})$. Natural aggregates, i.e., quarried hard rocks, are neither tested nor regulated for these parameters in most EU member states, e.g., Austria, prior to using them as a construction material. The purpose of this study was to relate the mineralogy to the leachability of natural aggregates with a special emphasis on PEPE and to interpret these findings in comparison with EAF slags. Five samples of Austrian rocks were investigated by polarization microscopy, electron probe microanalyses (EPMA), X-ray diffraction (XRD), and leaching tests as well as by hydrogeochemical modelling using LeachXS ${ }^{\mathrm{TM}}$. Two samples showed elevated total contents of $\mathrm{Cr}$, Ni, and Mo which were present as $\mathrm{Cr}$-spinel, $(\mathrm{Fe}, \mathrm{Mg})(\mathrm{Al}, \mathrm{Cr})_{2} \mathrm{O}_{4}, \mathrm{Ni}$-olivine, $(\mathrm{Fe}, \mathrm{Mg}, \mathrm{Ni})_{2} \mathrm{SiO}_{4}$, and molybdenite, $\mathrm{MoS}_{2}$. Whereas the former two phases also controlled the leaching of $\mathrm{Cr}$ and $\mathrm{Ni}$, the observed leaching of Mo was higher than expected in the case of solubility control by molybdenite. In summary, the leachability of PEPE in natural and industrial aggregates was controlled by similar mineralogical mechanisms.

Keywords: Mineralogy; leachability; rocks; slags; environmental assessment

\section{Introduction}

Every year about 100 million tons of constructional aggregates are used in Austria [1] and 3.2 billion tons in the EU [2]. Besides natural rocks, industrial aggregates, e.g., steel slags, and recycled aggregates obtained from construction and demolition waste are used for construction purposes. In contrast to natural rocks, for industrial and recycled aggregates, not only geological, physical-technical, and chemical [3] properties but also the environmental impact has to be assessed prior to application. According to the Recycling Construction Materials Ordinance (RCMO) the total contents of $\mathrm{Cd}, \mathrm{Cr}$, Mo, $\mathrm{Tl}$, and $\mathrm{W}$ (industrial aggregates) and $\mathrm{As}, \mathrm{Pb}, \mathrm{Cd}, \mathrm{Co}, \mathrm{Cr}, \mathrm{Cu}, \mathrm{Ni}, \mathrm{Hg}$, and $\mathrm{Zn}$ (recycled aggregates) are regulated in Austria [4] because these are considered as environmentally problematic.

For Austrian natural rocks, there is no regulation with regard to the environmental risks resulting from contaminants in the material. Data on the average total element contents of rocks in Austria are summarised in the Geochemical Atlas of the Republic of Austria [5]. Data for fluorine are missing for Austria, but its mineralogy and geochemistry is generally known [6] and related to the alkalinity of 
igneous rocks [7]. These elements can either form distinct mineral phases or substitute for other major elements, which are summarized in Supplementary Table S1.

In addition to the total concentrations of certain elements, leached amounts are also regulated for industrial and recycled aggregates. Elements whose leachable contents are regulated in Austria include $\mathrm{Ba}, \mathrm{Cd}, \mathrm{Cr}, \mathrm{Co}, \mathrm{Cu}, \mathrm{Ni}, \mathrm{Mo}, \mathrm{Tl}, \mathrm{V}, \mathrm{W}, \mathrm{Cl}$, and $\mathrm{F}$ (Federal Ministry for Agriculture and Forestry, Environment and Waste Management) [4]. As the environmental impact of chemical elements depends on their mineralogy and the hydrogeochemical conditions, all elements which are regulated in the $\mathrm{RCMO}$, either with respect to total or with respect to leachable contents, are referred to as potentially environmentally problematic elements (PEPE) in this study. Leaching, i.e., the release of chemical elements from the solid into the aqueous phase, is experimentally determined by standardized leaching tests for which the samples are stirred (e.g., EN 1744-3 [8]) or shaken (e.g., DIN 19529 [9] or EN 12457-1 to -4 [10]) with an aqueous solution or where the solution percolates through the material in a column test (e.g., EN 14405 [11] or DIN 19528 [12]). In most of these tests the $\mathrm{pH}$, which has a high impact on the release of different elements, stabilizes due to the dissolution equilibrium of the material, whereas in $\mathrm{pH}$ dependence tests (e.g., EN 14429 [13]) it is adjusted by acid and/or base addition. The effect of $\mathrm{pH}$ on the solubility of mineral phases in steel slags has also been investigated with respect to metal recovery by bioleaching [14]. Besides the $\mathrm{pH}$ value, other factors, e.g., the particle size of the samples, the duration of the test, and the liquid to solid (L/S) ratio influence the leaching behaviour. Generally, it is assumed that the leaching of PEPE from natural rock is insignificant [15]. Scientific data on the leachability of natural rocks is limited but they indicate that in general only small amounts of heavy metals and sulphur are released, the values normally being lower compared to secondary raw materials [16]. However, for some elements (e.g., Zn, Ni and Co) higher leached concentrations were detected in natural rocks than in blast furnace slags [17].

The mineralogy and mobility of chemical elements have long been studied with respect to the weathering of rocks and formation of supergene ore deposits, but not by standardized leaching tests used in waste management. More recent studies have dealt with $\mathrm{Cr}$ enrichment in a limonitic horizon of a soil formed by weathering of an ultramafic rock [18]; release of $\mathrm{Ni}$ in ultramafic rocks from minerals like olivine $\left((\mathrm{Mg}, \mathrm{Fe}, \mathrm{Ni})_{2} \mathrm{SiO}_{4}\right)$ and secondary fixation in serpentine $\left(\left(\mathrm{Mg}, \mathrm{Fe}, \mathrm{Ni}_{6}\right)_{6} \mathrm{Si}_{4} \mathrm{O}_{10}(\mathrm{OH})_{8}\right)$ and smectite [19]; and release of Mo from primary mineral phases and its adsorption onto iron hydroxides during granite weathering [20]. However, the few studies which address the leachability of PEPE from natural rocks (e.g., [17]) are still insufficiently linked to this fundamental mineralogical knowledge. Thus, the aim of this study is to investigate the leaching behaviour of PEPE like heavy metals from natural rocks and to link it to mineralogical data.

\section{Materials and Methods}

Crushed samples $(0.15-1.00 \mathrm{~kg}$ ) of four different rock materials used for road construction (A: quaternary gravel, B: diabase-greywacke mixture, C: serpentinite, and D: amphibolite breccia; NB: non-scientific trade names) were obtained in five different size fractions ( $<2 \mathrm{~mm}, 2-4 \mathrm{~mm}, 4-8 \mathrm{~mm}$, 8-11 $\mathrm{mm}$, and 11-16 mm) from commercial suppliers. Due to the non-disclosure agreement with the suppliers, the name of sample provider and sample provenance could not have been given. Sample designations refer to the particle size of the 'as received' materials. For sample $C$, an additional new sample was obtained from the same supplier and location $\left(C_{n}\right)$. Samples B and D were separated manually for mineralogical analysis because sample $B$ turned out to be a mixture of diabase and greywacke (B1: diabase, B2: greywacke) and sample D consisted of red and green components (D1: amphibolite breccia red and D2: amphibolite breccia green). An additional sample (E: Mo-bearing gneiss) which is not used in road construction but interesting with respect to the relation between mineralogy and leachability of Mo, was taken during a field campaign in the Reichenspitze area, Hohe Tauern. The representativity of samples for any petrographic unit or production charge is not claimed, but also not relevant for the purpose of this study, which deals with the release mechanisms of PEPE. 
One polished thin section of each sample (B1, B2, $C_{n}, \mathrm{D} 1, \mathrm{D} 2$, and E) was prepared and characterized by optical microscopy in transmitted (Olympus BX40F4) and reflected light (Zeiss AXIO Scope A.1), the latter equipped with a digital camera (Zeiss AxioCam). The same samples were subsequently used for electron probe microanalyses (EPMA) using the JEOL JXA 8200 instrument installed at the Chair of Resource Mineralogy, Montanuniversität Leoben. The polished sections were carbon coated (EMITECH K950X), to minimize charging under the electron beam. Spot measurements and element maps of mineral phases were conducted using wavelength-dispersive spectrometers (WDS). The instrument was operated in high vacuum $\left(<1.6510^{-5} \mathrm{mbar}\right)$, with $15 \mathrm{kV}$ acceleration voltage, $10 \mathrm{nA}$ beam current (on Faraday cup), and with beam diameter set to spot size $(\approx 1 \mu \mathrm{m})$. For all quantitative analyses by EPMA, K $\alpha$ lines were used (except for Mo, where L $\alpha$ was used); the counting time was $20 \mathrm{~s}$ (40 s for Mo) for the peak and $10 \mathrm{~s}$ (20 s for Mo) for the background. For details and net lower limits of detection (LLD) see Supplementary Table S2. The number of analyses performed for each mineral is given in Supplementary Tables S4 and S5.

For chemical analyses of samples A, B, C, C $n$, D, and E, bulk sample material was comminuted in a jaw crusher to $<0.5 \mathrm{~mm}$, then split to subsample portions $<50 \mathrm{~g}$ by coning and quartering. The subsamples were ground to $<63 \mu \mathrm{m}$ for analysis. The analyses were conducted at the Chair of Waste Processing Technology and Waste Management, Montanuniversität Leoben after total digestion according to EN 13656 [21]. The chemical composition was determined according to EN ISO 17294-2 [22] by inductively coupled plasma mass spectroscopy (ICP-MS, Agilent 7500ce). For samples $\mathrm{C}_{\mathrm{n}}$ and $\mathrm{E}$ additionally the sulphur content (inductively coupled plasma optical emission spectroscopy, ICP-OES, Varian Vista MPX CCD Simultan, based on EN ISO 11885 [23]), the fluorine content after alkaline digestion (ion chromatography, IC, Dionex ICS 2000, Chromeleon software, EN ISO 10304-1 [24]), and the $\mathrm{Cr}(\mathrm{VI})$ content (photometrically according to DIN 38405-24 [25]) were determined. The modal mineral composition of the fractions $<2 \mathrm{~mm}$ and $11-16 \mathrm{~mm}$ was investigated by $\mathrm{X}$-ray powder diffraction (XRD) analysis. The powdered samples were analyzed using a PANalytical X'Pert Pro diffraction instrument $(\mathrm{CoK} \alpha$ radiation $(\lambda=1.79 \AA), 40 \mathrm{~mA}, 45 \mathrm{kV})$ and the PANalytical HighScore Plus software package at the Institute of Applied Geosciences, Graz University of Technology. Diffractograms were automatically semi-quantified. The resulting net LLD are in the order of $2-5 \mathrm{wt} \%$, meaning that minerals may be present in lower concentrations but are not detected by XRD.

Particle size specific leaching tests for samples A-D were conducted according to EN 12457-4 at the Chair of Waste Processing Technology and Waste Management, Montanuniversität Leoben, in order to assess the impact of the particle size on leaching. One hundred grams of non-comminuted sample material and $1000 \mathrm{~g}$ deionised water were shaken for $24 \mathrm{~h}\left(7 \mathrm{~min}^{-1}\right)$. Solids were removed by sedimentation and subsequent centrifugation. The $\mathrm{pH}$ and the conductivity of the leachate were determined and the anions were analyzed by ion chromatography (IC, Dionex ICS 2000) according to EN ISO 10304-1 [24]. The total organic carbon (TOC) and the dissolved organic carbon (DOC) contents were determined according to EN 1484-3 [26]. The leachate was analyzed for chemical composition according to ÖNORM EN ISO 17294-2 [22] using ICP-MS (Agilent 7500ce).

Samples $C_{n}$ and $E$ were selected for $\mathrm{pH}$-dependent leaching tests (ÖNORM EN 14429 [13]). The samples were crushed to $<1 \mathrm{~mm}$ and a liquid/solid (L/S) ratio of 10 was used in the test. The $\mathrm{pH}$ was adjusted to 8 final values between $<2$ and $<12$ by adding $\mathrm{HNO}_{3}$ and $\mathrm{NaOH}$, respectively. The leaching tests were performed for $48 \mathrm{~h}$ and the electric conductivity and $\mathrm{pH}$ were monitored after $4 \mathrm{~h}, 44 \mathrm{~h}$, and $48 \mathrm{~h}$. The chemical composition of the leachates after centrifugation and filtration was analyzed by IC $\left(\mathrm{Cl}^{-}, \mathrm{F}^{-}, \mathrm{PO}_{4}{ }^{3-}, \mathrm{SO}_{4}{ }^{2-}\right), \mathrm{ICP}-\mathrm{MS}$, and photometry $(\mathrm{Cr}(\mathrm{VI}))$.

Additionally, percolation tests (according to EN 14405 [11]) on samples $C_{n}$ and E were performed to evaluate the leaching behaviour as a function of the liquid/solid (L/S) ratio. The cumulative $\mathrm{L} / \mathrm{S}$ ratio is the entire amount of water which has percolated the sample at a certain time, divided by the mass of the sample. The chemical evolution of the percolate reflects not only the behaviour in nature but also allows distinguishing between surface-wash off in the first fraction and continuous dissolution in the latter fractions. The samples ( $4 \mathrm{~kg}$ each) were crushed to $<10 \mathrm{~mm}$ and the particle size distribution was 
determined by sieving analyses. Similar particle size distributions were achieved by re-mixing the size fractions in the same ratio. The samples were then densely packed into polyethylene (PE) columns $(\mathrm{d}=11 \mathrm{~cm})$. A dense packing was achieved by compressing the samples with a falling weight, yielding a sample height of $25 \mathrm{~cm}$. The columns were closed on the top and at the bottom by caps with an outlet and with ceramic filters (pore size 10-16 $\mu \mathrm{m}$ ). A crown-shaped polypropylene (PP) device was used to secure the caps from eventual expansion due to swelling processes. The columns were saturated for $3 \mathrm{~d}$ to achieve equilibration. During the tests, purified water was pumped in an upward flow through the columns with a flow rate of $0.99 \mathrm{~mL} \mathrm{~min}^{-1}$. The electric conductivity, $\mathrm{pH}$, and Eh of the leachate were analyzed every $5 \mathrm{~min}$. A cumulative L/S ratio was calculated by dividing the cumulative mass of the percolate that has passed through the column at a certain time by the dry mass of the sample in the column (4 kg). Samples were taken after cumulative L/S ratios of $0.1,0.2,0.5,1,2,5$, and 10 . The total experimental duration was $8 \mathrm{~d}, 58 \mathrm{~min}$ for sample $\mathrm{C}_{\mathrm{n}}$ (shortened duration due to technical problems) and $28 \mathrm{~d}, 4 \mathrm{~h}$ for sample $\mathrm{E}$ (scheduled duration).

The maximum leachable concentrations of the individual elements (derived from the $\mathrm{pH}$ dependence leaching tests) were considered as the available concentrations and used as the input data for hydrogeochemical modelling with LeachXS ${ }^{\mathrm{TM}}$ (version 2.0.90) with the Orchestra geochemical modelling platform [27]. The aim of the modelling was to identify the mechanisms which control the leaching in samples $C_{n}$ and E, i.e., dissolution/precipitation or desorption/adsorption equilibria. The thermodynamic database of Minteq, version 4.0 (minteq.v4.dat) [28] was used. Additionally, minerals from the thermodynamic database from Lawrence Livermore National Laboratory [29] and Thermoddem.dat [30] as well as from additional literature were implemented. For sample C, the concentrations of 12 cations $(\mathrm{Al}, \mathrm{Ca}, \mathrm{Co}, \mathrm{Cr}, \mathrm{Cu}, \mathrm{Fe}, \mathrm{K}, \mathrm{Mg}, \mathrm{Mn}, \mathrm{Na}, \mathrm{Ni}$, and $\mathrm{Si}$ ) and 3 anions $(\mathrm{Cl}$, $\mathrm{CO}_{3}$ (estimated), and $\mathrm{SO}_{4}$ ) were implemented as primary entities. For sample $\mathrm{E}$, the concentrations of 18 cations ( $\mathrm{Ag}, \mathrm{Al}, \mathrm{Ba}, \mathrm{Ca}, \mathrm{Cr}, \mathrm{Cu}, \mathrm{Fe}, \mathrm{K}, \mathrm{Mg}, \mathrm{Mn}, \mathrm{Mo}, \mathrm{Na}, \mathrm{Ni}, \mathrm{Pb}, \mathrm{Si}, \mathrm{Sr}, \mathrm{V}$, and $\mathrm{Zn}$ ) and 5 anions (Cl, $\mathrm{CO}_{3}$ (estimated), $\mathrm{F}, \mathrm{NO}_{3}, \mathrm{PO}_{4}$, and $\mathrm{SO}_{4}$ ) were used. For both samples, the adsorption onto hydrous ferric oxides (HFO, sample $\mathrm{C}_{\mathrm{n}}: 500 \mathrm{mg} / \mathrm{kg}$, sample E: $300 \mathrm{mg} / \mathrm{kg}$ ) was enabled as these phases usually form in natural systems under oxidizing conditions. The sum of the negative logarithm of electron concentration, pe, and $\mathrm{pH}$ was set to 12 . This value was also chosen in another study for a steel slag [31]. Those phases containing $\mathrm{Cr}, \mathrm{Cu}$, and $\mathrm{Ni}$ (for sample $\mathrm{Cn}$ ) and $\mathrm{Mo}$ (for sample E) used for hydrogeochemical modelling are listed in Supplementary Table S3.

\section{Results}

\subsection{Chemical Composition}

The results of the chemical analyses obtained by ICP-MS are displayed in Table 1. In order to evaluate the total contents of PEPE in the investigated natural rocks, the RCMO, which regulates the total contents of recycled and industrial aggregates, serves as a comparison. However, it has to be mentioned that this regulation is (i) not valid for natural aggregates and (ii) is based on aqua regia instead of total digestion, which often yields lower concentrations due to the incomplete dissolution of the sample material. However, to assess the environmental relevance, it can be mentioned that the Cr concentrations in the investigated samples $(45-1033 \mathrm{mg} / \mathrm{kg}$, with sample C showing the highest concentrations) are in a similar range as the limit values for various quality classes $(90-2500 \mathrm{mg} / \mathrm{kg})$, defined in the RCMO. Photometry reveals that $0.24 \mathrm{mg} / \mathrm{kg}$ of $\mathrm{Cr}$ are present as $\mathrm{Cr}(\mathrm{VI})$ in sample $\mathrm{C}_{\mathrm{n}}$. The cobalt concentrations ranged between 12 and $100 \mathrm{mg} / \mathrm{kg}$ (also with sample $C_{n}$ showing the highest concentrations), hence they fluctuate around the limit value for the class U-E (application for rail and road construction and for hydraulically or bituminously bound materials) of $50 \mathrm{mg} / \mathrm{kg}$, which is, however, not valid for geogenic contents (i.e., enrichments in the recycled aggregates which is due to the enrichment in the former natural aggregate). 
Table 1. Chemical bulk composition of the investigated samples A: quaternary gravel, B: diabase greywacke mixture, C: serpentinite; D: amphibolite breccia; terminology is according to the supplier and not according to scientific rock classification. Bold script: elements whose total contents are regulated in Austrian legislation for industrial and recycled aggregates. All results refer to dry matter (DM). n.a.: not analyzed. The range of limit values for the recycled and industrial aggregates of different quality classes [4] are given for orientation only as they are (i) not valid for natural aggregates and (ii) refer to aqua regia digestion. The estimated extended relative measurement uncertainty according to the EURACHEM/CITAC guideline is in the range of 30 to $35 \%$ for most elements.

\begin{tabular}{|c|c|c|c|c|c|c|c|c|c|c|c|c|c|c|c|c|c|c|c|c|c|c|c|c|c|}
\hline $\begin{array}{l}\text { Element } \\
\text { group }\end{array}$ & Element & Unit & & & A & & & & & B & & & & & C & & & $C_{n}$ & & & D & & & $\mathrm{E}$ & $\begin{array}{c}\text { Limit value } \\
\text { range }\end{array}$ \\
\hline \multicolumn{3}{|c|}{$\begin{array}{l}\text { Particle size }(\mathrm{mm}) \\
\end{array}$} & $<2$ & $2-4$ & $4-8$ & $8-11$ & $11-16$ & $<2$ & $2-4$ & $4-8$ & $8-11$ & $11-16$ & $<2$ & $2-4$ & $4-8$ & $8-11$ & $11-16$ & & $<2$ & $2-4$ & $4-8$ & $8-11$ & $11-16$ & & \\
\hline \multirow{2}{*}{\multicolumn{3}{|c|}{$\begin{array}{l}\mathrm{Na} \\
\mathrm{Mg}\end{array}$}} & 8 & 8 & 7 & 7 & 4 & 12 & 13 & 12 & 12 & 11 & 0.7 & 0.5 & 0.7 & 0.9 & 1.3 & 0.5 & 14 & 14 & 14 & 14 & 13 & 37 & - \\
\hline & & & 24 & 13 & 23 & 24 & 21 & 19 & 19 & 15 & 18 & 24 & 77 & 61 & 120 & 123 & 139 & 229 & 27 & 24 & 27 & 33 & 24 & 0.4 & - \\
\hline \multicolumn{3}{|c|}{$\begin{array}{l}\mathrm{Mg} \\
\mathrm{Al}\end{array}$} & 42 & 43 & 44 & 45 & 38 & 57 & 59 & 47 & 58 & 61 & 1.3 & 0.6 & 1.2 & 1.2 & 6.3 & 1.9 & 51 & 45 & 50 & 56 & 53 & 31 & - \\
\hline Major & $\mathrm{Si}$ & $\mathrm{g} / \mathrm{kg}$ & 125 & 200 & 155 & 172 & 91 & 191 & 209 & 154 & 202 & 182 & 127 & 137 & 123 & 112 & 90 & 159 & 147 & 150 & 148 & 165 & 141 & 263 & - \\
\hline \multirow{11}{*}{ Elements } & $\mathrm{K}$ & \multirow[t]{11}{*}{$\mathrm{DM}$} & 5 & 9 & 9 & 10 & 9 & 11 & 11 & 10 & 12 & 13 & 0.08 & 0.09 & 0.03 & 0.03 & 0.95 & $<0.01$ & 3 & 3 & 2 & 3 & 7 & 11 & - \\
\hline & $\mathrm{Ca}$ & & 82 & 73 & 102 & 118 & 161 & 13 & 14 & 15 & 8 & 18 & $<0.3$ & $<0.3$ & 0.3 & $<0.3$ & 4.5 & 7 & 60 & 50 & 58 & 59 & 65 & 0.9 & - \\
\hline & $\mathrm{Ti}$ & & 5 & 3 & 4 & 4 & 3 & 9 & 10 & 9 & 9 & 10 & 0.2 & 0.1 & 0.1 & 0.1 & 0.3 & 0.07 & 8 & 8 & 8 & 9 & 7 & 0.2 & - \\
\hline & $\mathrm{Fe}$ & & 47 & 27 & 41 & 35 & 30 & 58 & 58 & 55 & 57 & 63 & 43 & 49 & 48 & 43 & 41 & 55 & 76 & 72 & 79 & 84 & 63 & 2 & - \\
\hline & $\mathrm{Li}$ & & 20 & 25 & 31 & 31 & 27 & 32 & 32 & 33 & 34 & 37 & 0.5 & $<0.3$ & 0.3 & 0.4 & 3.3 & 1.4 & 13 & 12 & 13 & 15 & 21 & 4 & - \\
\hline & $\mathrm{P}$ & & 410 & 542 & 635 & 572 & 648 & 1056 & 1050 & 951 & 1046 & 1019 & 19 & 19 & 5 & 5 & 31 & 33 & 404 & 402 & 421 & 462 & 457 & 100 & - \\
\hline & $\mathrm{Cr}$ & & 75 & 60 & 73 & 98 & 56 & 46 & 45 & 55 & 53 & 55 & 582 & 548 & 946 & 755 & 1033 & 780 & 107 & 93 & 100 & 40 & 124 & $<3$ & $90-2500$ \\
\hline & Mn & & 897 & 725 & 1116 & 854 & 872 & 850 & 871 & 832 & 798 & 1049 & 752 & 764 & 775 & 679 & 650 & 960 & 1375 & 1292 & 1416 & 1559 & 1312 & 77 & \\
\hline & Co & & 24 & 13 & 16 & 17 & 12 & 21 & 21 & 23 & 22 & 25 & 83 & 89 & 95 & 85 & 78 & 100 & 42 & 40 & 43 & 53 & 32 & 1 & 50 \\
\hline & $\mathrm{Ni}$ & & 39 & 47 & 56 & 62 & 22 & 19 & 20 & 25 & 24 & 23 & 1478 & 1718 & 1780 & 1563 & 1395 & 2580 & 63 & 58 & 62 & 85 & 83 & $<3$ & $60-500$ \\
\hline & $\mathrm{Cu}$ & & 36 & 10 & 12 & 18 & 8 & 16 & 13 & 19 & 15 & 8 & 7 & 11 & 9 & 6 & 6 & 40 & 77 & 58 & 60 & 50 & 49 & 7 & $90-500$ \\
\hline \multirow{8}{*}{$\begin{array}{l}\text { Ilace } \\
\text { Elements }\end{array}$} & $\mathrm{Zn}$ & $\mathrm{mg} / \mathrm{kg}$ & 103 & 93 & 55 & 75 & 62 & 172 & 158 & 159 & 132 & 126 & 22 & 23 & 25 & 21 & 31 & 28 & 9 & 96 & 99 & 110 & 93 & 6 & $450-1000$ \\
\hline & As & $\mathrm{DM}$ & 9 & 16 & 22 & 16 & 19 & 10 & 12 & 11 & 10 & 8 & 5 & 4 & $<3$ & $<3$ & 5 & 8 & 10 & 10 & 10 & & & $<3$ & $50-200$ \\
\hline & $\mathrm{Sr}$ & & 165 & 238 & 246 & 257 & 295 & 161 & 176 & 142 & 138 & 159 & 8 & 5 & 4 & 4 & 11 & 2 & 144 & 133 & 141 & 150 & 209 & 16 & - \\
\hline & Mo & & $<3$ & $<3$ & $<3$ & $<3$ & $<3$ & $<3$ & $<3$ & $<3$ & $<3$ & $<3$ & $<3$ & $<3$ & $<3$ & $<3$ & $<3$ & 3 & $<3$ & $<3$ & $<3$ & $<3$ & $<3$ & 49500 & 50 \\
\hline & $\mathrm{Cd}$ & & $<0.5$ & $<0.5$ & $<0.5$ & $<0.5$ & $<0.5$ & 0.5 & $<0.5$ & 0.5 & 0.7 & 0.5 & $<0.5$ & $<0.5$ & $<0.5$ & $<0.5$ & $<0.5$ & 0.2 & $<0.5$ & $<0.5$ & $<0.5$ & 0.7 & $<0.5$ & $<0.5$ & $1.1-4$ \\
\hline & $\mathrm{Ba}$ & & 165 & 305 & 307 & 327 & 251 & 612 & 575 & 489 & 606 & 674 & 16 & $<1$ & 5 & 3 & 32 & 3 & 66 & 67 & 66 & 76 & 225 & 150 & $1.1-7$ \\
\hline & w & & 0.6 & 0.5 & 0.7 & 0.9 & 0.6 & 0.6 & 0.7 & 0.7 & 0.8 & 0.6 & $<0.3$ & $<0.3$ & $<0.3$ & $<0.3$ & 0 & 8 & $<0.5$ & $<0.5$ & $<0.5$ & $<0.5$ & 1 & & 450 \\
\hline & $\mathrm{Hg}$ & & $<0.3$ & $<0.3$ & $<0.3$ & $<0.3$ & $<0$ & $<0.3$ & $<0.3$ & $<0.3$ & $<0.3$ & $<0.3$ & $<0$ & $<0$ & $<0$ & $<0$ & $<0$ & n.a. & $<0.3$ & $<0.3$ & $<0.3$ & $<0.3$ & $<0.3$ & $<0.3$ & $0.7-2$ \\
\hline
\end{tabular}


Nickel concentrations are significantly higher in sample C (1395-1780 mg/kg) compared to samples $\mathrm{A}, \mathrm{B}$, and D (19-85 mg/ $\mathrm{kg}$ ) and to RCMO limit values $(60-500 \mathrm{mg} / \mathrm{kg}$, not valid for geogenic enrichments). Copper concentrations in sample D (49-77 mg/kg) are higher than in samples A, B, and C $(6-36 \mathrm{mg} / \mathrm{kg})$ but lower than limit values for anthropogenic and geogenic contents for recycled aggregates which are 90 and $500 \mathrm{mg} / \mathrm{kg}$, respectively. Zinc concentrations in sample $C(21-31 \mathrm{mg} / \mathrm{kg})$ are lower than in samples A, B, and D (55-172 $\mathrm{mg} / \mathrm{kg})$ but even in those samples they are far below the limit values (450-1000 mg/kg). Arsenic concentrations are up to $22 \mathrm{mg} / \mathrm{kg}$ which is also far below the limit values of 50 to $200 \mathrm{mg} / \mathrm{kg}$. Mercury could not be detected in any of the samples. Thallium was present in one sample $(0.4 \mathrm{mg} / \mathrm{kg})$ and $\mathrm{Cd}$ was only detected in traces in a few samples but was always below the limit value of $1.1 \mathrm{mg} / \mathrm{kg}$. The same accounts for $\mathrm{W}$ which was detected in concentrations below $1.3 \mathrm{mg} / \mathrm{kg}$ which is insignificant compared with the limit value of $450 \mathrm{mg} / \mathrm{kg}$. Lead concentrations are always below $26 \mathrm{mg} / \mathrm{kg}$ which is again far below the limit values $(150-500 \mathrm{mg} / \mathrm{kg})$. In sample E, Mo ( $5 \mathrm{wt} \%$ ) is the PEPE with the highest concentration whereas $\mathrm{F}$ is only present with a concentration of $160 \mathrm{mg} / \mathrm{kg}$. All other PEPE are below $20 \mathrm{mg} / \mathrm{kg}$ in sample E.

In summary, the total contents of $\mathrm{Cr}$ and $\mathrm{Ni}$ in sample $\mathrm{C}$ and Mo in sample $\mathrm{E}$ are the only elements which are in the range of possibly environmentally problematic concentrations. Other elements like $\mathrm{V}$ in sample D (194-299 $\mathrm{mg} / \mathrm{kg}$ ) exceed the average concentrations of the upper continental crusts (e.g., $98 \mathrm{mg} / \mathrm{kg} \mathrm{V} \mathrm{[32])} \mathrm{but} \mathrm{are} \mathrm{not} \mathrm{regulated} \mathrm{in} \mathrm{its} \mathrm{total} \mathrm{content} \mathrm{by} \mathrm{RCMO.}$

\subsection{Mineralogical Composition}

The mineralogical composition of samples A-D obtained by XRD is displayed in Table 2. None of the major to minor rock-forming minerals identified in any of the investigated samples contains potentially environmentally problematic elements in their stoichiometric formula. Because of the heterogeneity of sample A-the components of this gravel are petrographically highly variable-no detailed petrographic analyses were conducted. However, the texture and bulk mineralogical composition (calcite and various silicates) supports the classification as a clastic sediment (commercial terminology: quaternary gravel). Sample B is a mixture of silicate rocks composed of quartz, albite, chlorite, and hornblende. It is marketed as diabase. For sample $\mathrm{C}$, the composition with serpentine, chlorite, and olivine is in good agreement with the commercial classification as serpentinite. The same is valid for sample $\mathrm{D}$ which is composed of hornblende, albite, chlorite, and diopside and named amphibolite breccia by the supplier.

Table 2. Mineralogical composition (wt \%) of the investigated samples (same as in Table 1) derived from XRD. A: quaternary gravel, B: diabase greywacke mixture, C: serpentinite, D: amphibolite breccia; terminology is according to the supplier and not according to scientific rock classification. n.i.: not identified. The relative error is in the range of $20-30 \%$.

\begin{tabular}{|c|c|c|c|c|c|c|c|c|c|}
\hline \multirow{2}{*}{$\frac{\text { Sample }}{\text { Particle Size }(\mathrm{mm})}$} & \multirow[t]{2}{*}{ Stoichometry } & \multicolumn{2}{|c|}{$\mathbf{A}$} & \multicolumn{2}{|c|}{ B } & \multicolumn{2}{|c|}{$\mathrm{C}$} & \multicolumn{2}{|c|}{ D } \\
\hline & & $<2$ & $11-16$ & $<2$ & $11-16$ & $<2$ & $11-16$ & $<2$ & $11-16$ \\
\hline Quartz (Qz) & $\mathrm{SiO}_{2}$ & 38 & 17 & 24 & 21 & n.i. & 5 & 7 & 8 \\
\hline Calcite $(\mathrm{Cc})$ & $\mathrm{CaCO}_{3}$ & 13 & 43 & 3 & 0 & n.i. & n.i. & n.i. & n.i. \\
\hline $\begin{array}{l}\text { Illite (Ilt) / Muscovite } \\
\text { (Ms) }\end{array}$ & $\left(\mathrm{K}, \mathrm{H}_{3} \mathrm{O}\right) \mathrm{Al}_{3} \mathrm{Si}_{3} \mathrm{O}_{10}(\mathrm{OH})_{2}$ & 9 & 14 & 11 & 14 & n.i. & n.i. & n.i. & n.i. \\
\hline Annite (Ann) & $\mathrm{KFe}_{3} \mathrm{AlSi}_{3} \mathrm{O}_{10}(\mathrm{OH}, \mathrm{F})_{2}$ & 7 & n.i. & n.i. & n.i. & n.i. & n.i. & n.i. & n.i. \\
\hline Chlorite (Chl) & $\left(\mathrm{Mg}_{,} \mathrm{Fe}^{2+}\right)_{5} \mathrm{Al}\left(\mathrm{Si}_{3} \mathrm{Al}\right) \mathrm{O}_{10}(\mathrm{OH})_{8}$ & 6 & 4 & 23 & 17 & 28 & 26 & 18 & 12 \\
\hline Diopside (Di) & $\mathrm{CaMgSi}_{2} \mathrm{O}_{6}$ & n.i. & n.i. & n.i. & n.i. & n.i. & n.i. & 12 & 9 \\
\hline Ankerite (Ank) & $\mathrm{Ca}\left(\mathrm{Fe}^{2+,} \mathrm{Mg}\right)\left(\mathrm{CO}_{3}\right)_{2}$ & 6 & n.i. & n.i. & 6 & n.i. & n.i. & n.i. & n.i. \\
\hline Actinolite (Act) & $\mathrm{Ca}_{2}\left(\mathrm{Mg}_{2.5-4.5}, \mathrm{Fe}^{2+}{ }_{0.5-2.5}\right) \mathrm{Si}_{8} \mathrm{O}_{22}(\mathrm{OH})_{2}$ & 2 & n.i. & n.i. & n.i. & n.i. & n.i. & n.i. & n.i. \\
\hline
\end{tabular}


Table 2. Cont.

\begin{tabular}{|c|c|c|c|c|c|c|c|c|c|}
\hline \multirow{2}{*}{$\frac{\text { Sample }}{\text { Hornblende }(\mathrm{Hbl})}$} & \multirow{2}{*}{$\begin{array}{c}\text { Stoichometry } \\
\mathrm{Ca}_{2}(\mathrm{Na}, \mathrm{K})_{0.5-1}(\mathrm{Mg}, \mathrm{Fe})_{3-4}\left(\mathrm{Fe}^{3+},\right. \\
\mathrm{Al}_{1-2} \mathrm{Al}_{2} \mathrm{Si}_{6} \mathrm{O}_{22}(\mathrm{O}, \mathrm{OH}, \mathrm{F})_{2}\end{array}$} & \multicolumn{2}{|c|}{$\mathbf{A}$} & \multicolumn{2}{|c|}{ B } & \multicolumn{2}{|c|}{$\mathrm{C}$} & \multicolumn{2}{|c|}{ D } \\
\hline & & n.i. & 10 & 5 & 20 & n.i. & n.i. & 34 & 36 \\
\hline Serpentine (Srp) & $\mathrm{Mg}_{6} \mathrm{Si}_{4} \mathrm{O}_{10}(\mathrm{OH})_{8}$ & n.i. & n.i. & n.i. & n.i. & 44 & 43 & n.i. & n.i. \\
\hline Talc (Tlc) & $\mathrm{Mg}_{3} \mathrm{Si}_{4} \mathrm{O}_{10}(\mathrm{OH})_{2}$ & n.i. & n.i. & n.i. & n.i. & 9 & 8 & n.i. & n.i. \\
\hline
\end{tabular}

Petrographic investigations of sample B1 revealed plagioclase, amphibole, pyroxene, and quartz as major phases, chlorite, and biotite are present as minor phases and titanite, ilmenite, rutile, and opaque phases as accessories (Figure 1). Some fractures are filled with calcite and quartz. For most phases, the microscopic investigations confirm XRD results but additionally indicate the presence of pyroxene and accessory minerals. The feldspar is plagioclase. The amphibole is a strongly pleochroic clinoamphibole showing oblique extinction, i.e., hornblende. Due to its fine-to medium-grained homogeneous texture the nomenclature as diabase is reasonable.

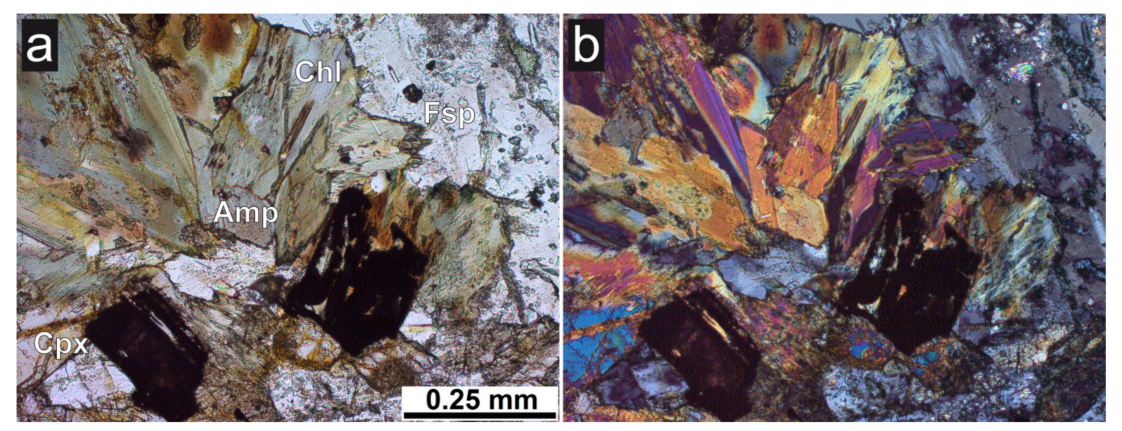

Figure 1. Photomicrographs of sample B1 in thin section. (a) and crossed nicols (B) a: Amphibole (Amp) and chlorite (Chl) showing greenish colors and pleochroism, clinopyroxene (Cpx) and feldspar (Fsp) are also major phases. (b): Under crossed polarizers, the low interference colors of the feldspars (plagioclase, grey) and the chlorite (anomalous bluish grey) become visible. Chlorite mainly forms by alteration of clinoamphibole (hornblende); both images transmitted light, plane parallel polarizers.

Reflected light microscopy revealed that besides ilmenite, rutile, pyrite $\left(\mathrm{FeS}_{2}\right)$, and pyrrhotite $(\mathrm{FeS})$, chalcopyrite $\left(\mathrm{CuFeS}_{2}\right)$ also occurs as accessory mineral (Figure 2). This is interesting as the total $\mathrm{Cu}$ contents in sample B were always below $20 \mathrm{mg} / \mathrm{kg}$, as are Ni values; the latter element can be enriched in Fe sulphides. However, due to the small amount of chalcopyrite present mineralogical and chemical composition are in good agreement and show a small amount of PEPE in sample B or B1, respectively.

EPMA analyses of sample B1 indicated the incorporation of $0.23 \mathrm{wt} \% \mathrm{~V}$ in titanite (Table S4) with enrichment towards the rim and of $0.07 \mathrm{wt} \% \mathrm{~V}$ in ilmenite. Substitution of V for Ti in titanite is in agreement with literature data [33]. Furthermore, $\mathrm{F}$ replaced $\mathrm{O}$ in pyroxene which is in agreement with literature data [34]. Elemental (WDS) mapping of a polyphase sulphide grain additionally revealed the presence of $\mathrm{Zn}$ bound to sphalerite (ZnS) (Figure 3). Zn, which is also a PEPE, shows higher concentrations in this sample compared to the other ones (Table 1 ). 

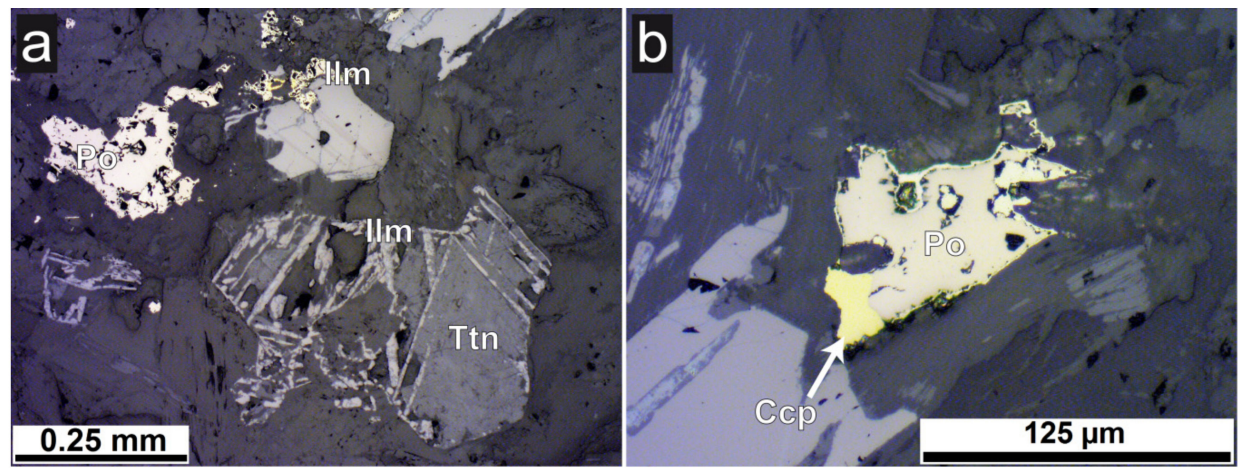

Figure 2. Photomicrographs of sample B1 in thin section. (a) Oriented ilmenite-rutile lamellae within titanite (Ttn), ilmenite (Ilm), and pyrrhotite (Po). (b) Polyphase sulphide grain with chalcopyrite (Ccp, yellow, with red arrow), pyrrhotite (Po) the latter with a reaction rim of another Fe sulphide; both images reflected light, plane parallel polarizers.

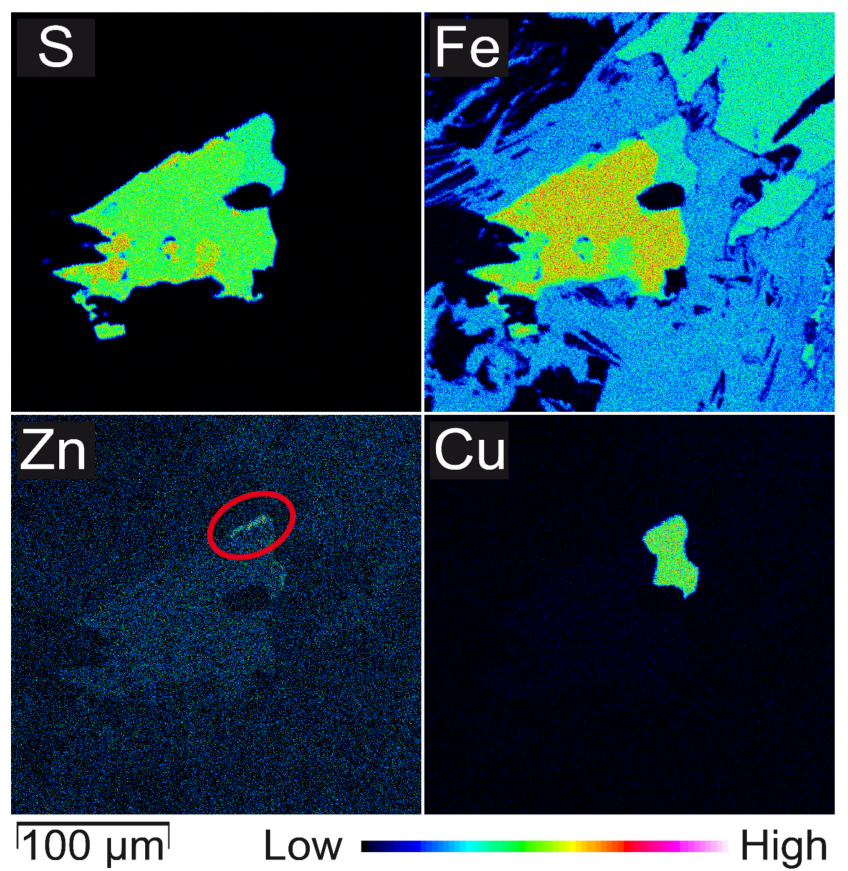

Figure 3. WDS elemental mappings ( $, \mathrm{Fe}, \mathrm{Zn}, \mathrm{Cu}$ ) of a polyphase sulphide grain of sample B1 (compare with Figure $2 b$ ). A thin area characterized by elevated $\mathrm{Zn}$ contents is displayed in the upper right corner of the grain (red marking in $\mathrm{Zn}$ map). The main grain is an intergrowth of pyrrhotite and another Fe sulphide phase (pyrite?). Cu (combined with Fe and S) indicates chalcopyrite.

Optical microscopy of sample B2 confirmed the XRD results with respect to the presence of phyllosilicates which form a fine-grained matrix in which larger grains of quartz and plagioclase are embedded. The rock is characterized by a clastic fabric, typical of siliciclastic sedimentary rocks. Chlorite, which is a major phase according to XRD, is present only as an accessory mineral together with iron hydroxides, clinopyroxene, and pyrite according to microscopy, probably due to the heterogeneity of the sample. Regarding PEPE, almost all quantitative EPMA analyses were below $0.1 \mathrm{wt} \%$. The name of greywacke as applied by the supplier is correct. For sample C, XRD analyses were confirmed by optical microscopy. Serpentine, which forms a fine-grained (often mesh-like) matrix, olivine, which occurs as fractured relict grains, and chlorite are major phases. Talc is an accessory phase (Figure 4). In addition, minor amounts of chromite were observed in the thin section, which was not identified via XRD. Chromite shows various degrees of alteration; typically with the development of a chemically distinct reaction rim (i.e., lower $\mathrm{Al}$ content) developing around the chromite core 
(Figure $4 b$ ). These results confirm the classification of the sample as serpentinite, or more precisely serpentinized meta-ultramafic rock, as a significant amount of non-metamorphic primary mineral phases is still present.
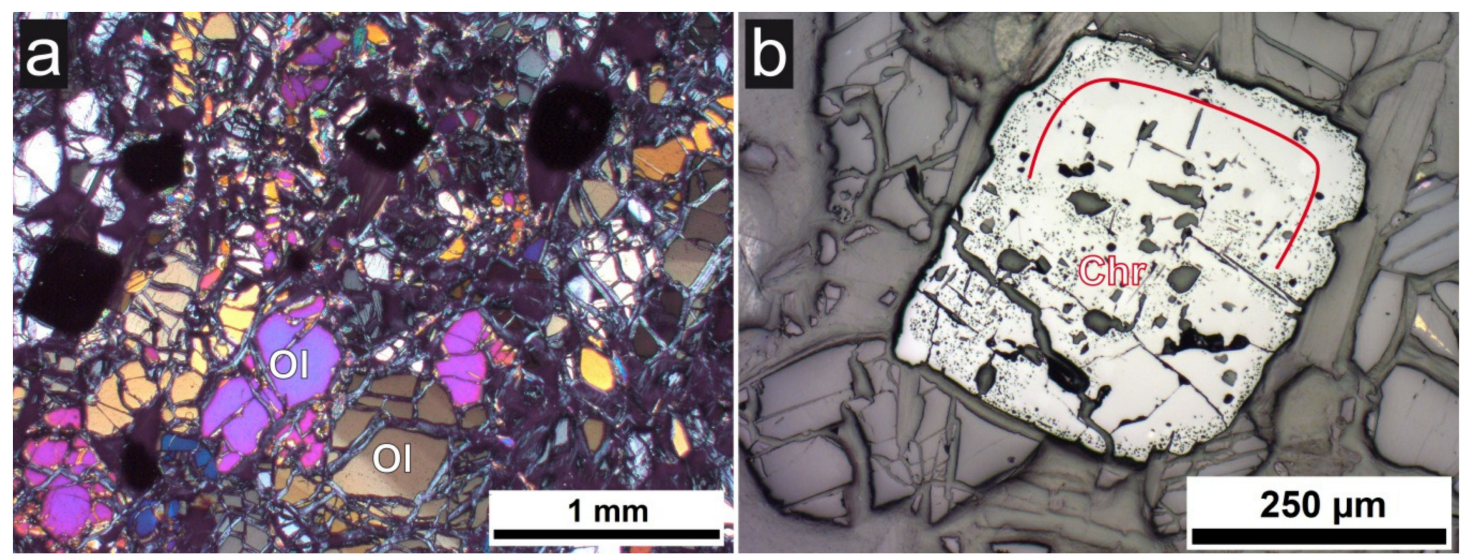

Figure 4. Photomicrographs of sample $\mathrm{C}$ in thin section. (a) Olivine $(\mathrm{Ol})$ showing mesh-like texture due to serpentinisation; transmitted light, crossed polarizers; (b) Chromite (Chr) showing strong alteration at the rim (red line); reflected light, plane parallel polarizer.

Chromite is the main carrier phase of $\mathrm{Cr}\left(56 \mathrm{wt} \% \mathrm{Cr}_{2} \mathrm{O}_{3}\right.$, number of analyzed spots $\left.(\mathrm{n})=27\right)$ in sample $\mathrm{C}$. However, EPMA results reveal that chlorite $\left(4.2 \mathrm{wt} \% \mathrm{Cr}_{2} \mathrm{O}_{3}, \mathrm{n}=2\right)$ and tremolite $(0.22 \mathrm{wt} \%$ $\mathrm{Cr}_{2} \mathrm{O}_{3}, \mathrm{n}=2$ ) also host significant, respectively minor amounts of $\mathrm{Cr}$ (Table S5), which is in agreement with literature data. $\mathrm{Ni}$ is bound to olivine $(0.26 \mathrm{wt} \% \mathrm{NiO}, \mathrm{n}=15)$, serpentine $(0.21 \mathrm{wt} \% \mathrm{NiO}, \mathrm{n}=5)$, chlorite $(0.16$ wt $\% \mathrm{NiO}, \mathrm{n}=4)$, and tremolite $(0.06$ wt $\% \mathrm{NiO}, \mathrm{n}=3)$. Despite low total $\mathrm{V}$ contents $(32 \mathrm{mg} / \mathrm{kg})$, EPMA results suggest that chromite contains $0.36 \mathrm{wt} \% \mathrm{~V}_{2} \mathrm{O}_{5}(\mathrm{n}=27)$ with chromite grains showing enrichment of $\mathrm{V}$ towards the rims. Compared to the bulk values, this would mean a 100-fold enrichment of the chromite with respect to $\mathrm{V}$.

Microscopic investigations of sample D1 (not shown) yielded a mineralogical composition of diopside, epidote, titanite, plagioclase, and quartz which are embedded in a fine-grained chlorite matrix with interlayered hematite and magnetite schlieren. This, in general, confirms the XRD results but adds titanite and hematite as further phases. Consequently, the rock name "amphibolite breccia" of this sample cannot be confirmed. Petrographically, this rock should rather be termed as metabasite, possibly as a low-grade metabasalt, or pyroclastic rock. EPMA revealed that $\mathrm{V}$ is incorporated in hematite $\left(0.33 \mathrm{wt} \% \mathrm{~V}_{2} \mathrm{O}_{5}, \mathrm{n}=3\right)$ and magnetite $(0.23 \mathrm{wt} \%, \mathrm{n}=35)$, the latter being also the host phase for $\mathrm{Cu}(0.15$ wt \% $\mathrm{CuO}, \mathrm{n}=9)$ and $\mathrm{Cr}\left(0.11\right.$ wt $\left.\% \mathrm{Cr}_{2} \mathrm{O}_{3}, \mathrm{n}=13\right)$.

Sample D2 consists of major to minor amphibole, plagioclase, quartz, chlorite, diopside, calcite, and accessory garnet, titanite, chalcopyrite, pyrite, pyrrhotite (microscopic images not shown). This is in accordance with XRD analyses and adds to the information on the accessory phases. The rock shows a brecciated texture with $\mathrm{cm}$-sized fragments embedded in a carbonate matrix. The cementing carbonate mineral is calcite. In this case, the commercial classification as amphibolite breccia is therefore applicable for sample D2. Besides chalcopyrite, which contributes to the total Cu content of $49-77 \mathrm{mg} / \mathrm{kg}$, titanite is of environmental relevance due to its incorporation of $0.45 \mathrm{wt} \% \mathrm{~V}_{2} \mathrm{O}_{5}$.

Sample E is a molybdenite-bearing gneiss which is described in detail in another study [35]. It is composed of feldspars and quartz with minor amounts of muscovite and molybdenite. This molybdenite occurs in irregular patches in polycrystalline aggregates with a grain size of up to $1 \mathrm{~cm}$ as well as disseminated in the quartz-feldspar matrix (Figure 5). The feldspars are plagioclase and alkali feldspar (microcline). A variety of rare accessory minerals including molybdenite and wulfenite has also been identified in a separate thesis [35]. It is suggested that molybdenite mineralization in this sample occurred due to the hydrothermal input of Mo and S. EPMA of the remaining phases indicate that molybdenite is the main Mo-bearing phase in this sample, but feldspars and muscovite contain 
$\mathrm{MoO}_{3}$ concentrations in the range of the detection limit $(0.06 \mathrm{wt} \%)$ which is 300 times more than the $0.2 \mathrm{mg} / \mathrm{kg}$ given by [36]. Interestingly, in another study of the same material wulfenite $\left(\mathrm{PbMoO}_{4}\right)$ was also found [35].

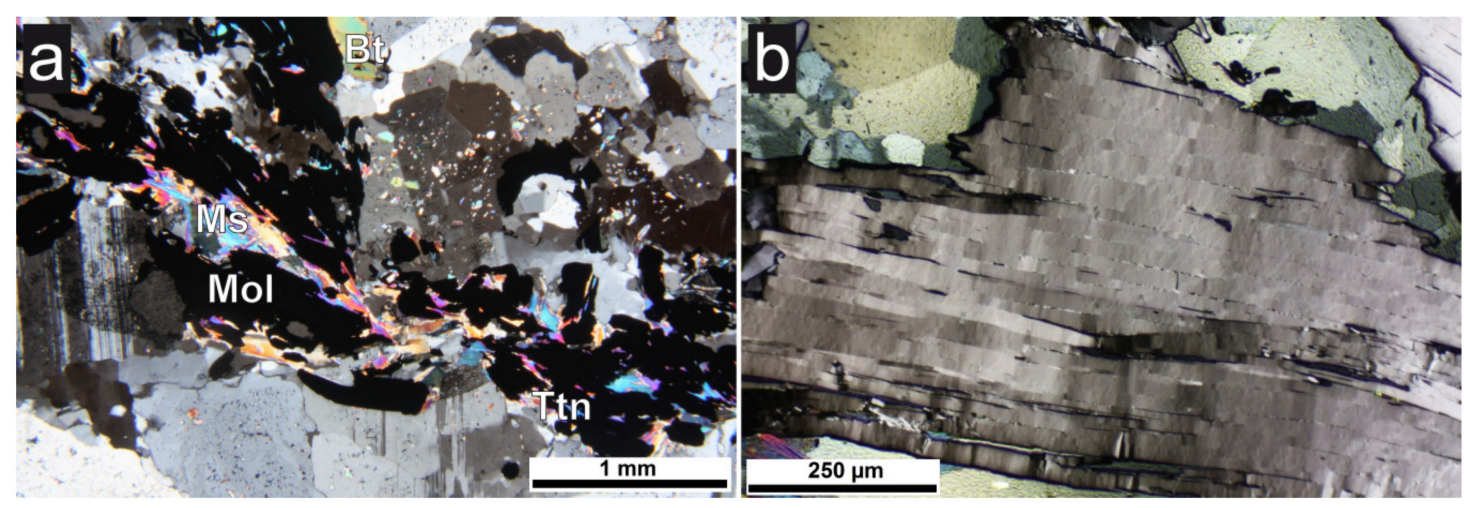

Figure 5. Photomicrographs of sample E in thin section. (a) Opaque molybdenite (Mol) with muscovite (Ms) and biotite (Bt) in quartz and feldspars. Transmitted light, crossed polarizers. (b) Molybdenite with perfect cleavage showing evidence of deformation expressed as undulose extinction. Reflected light, crossed polarizers.

\subsection{Leaching Behaviour}

Batch leaching tests (EN 12457-4) of samples A-D with an aqueous solution (initial $\mathrm{pH}=7$ ) (Table S6) showed that the reaction solutions of all samples became alkaline ( $\mathrm{pH}$ 9.2-9.8) without significant differences between the samples but lower $\mathrm{pH}$ values were obtained with lower particle size. This might result from the more rapid carbonation because of increasing specific surface area. Accelerated reaction with the aqueous solution for finer particle sizes is also supported by the increase in electric conductivity values with decreasing particle size. This is especially noted for sample C where the electric conductivity increased from 47 to $116 \mu \mathrm{S} / \mathrm{cm}$; in other samples, it increased up to $67 \mu \mathrm{S} / \mathrm{cm}$. This means that the system is not in equilibrium for coarser particle sizes so that dissolution kinetics play a role [37].

The leachable contents of the investigated samples are graphically displayed in Figure 6 for Cr, $\mathrm{Cu}, \mathrm{Ni}$, and V; the complete data are presented in Table S6. Even though the limit values of the RCMO are not valid for natural aggregates, a comparison to RCMO was made to evaluate the leaching of PEPE, irrespective of statutory law, which excludes natural aggregates from this regulation. In general, the leaching of PEPE from the investigated samples is very low and commonly no clear correlation with the particle size can be established. For some elements a clear difference between the samples was observed, e.g., sample $\mathrm{C}$ shows significantly less $\mathrm{V}$ leaching in all particle size fractions than samples $\mathrm{A}$, $\mathrm{B}$, and D (Figure 6a). For other elements the leachable concentrations vary among different particle size fractions of one sample by one order of magnitude, e.g., Ni in sample C (Figure 6c). Hence, no distinct difference between different samples could be observed. Solely for the fraction 2-4 mm of sample D and the fractions $8-11 \mathrm{~mm}$ and $11-16 \mathrm{~mm}$ of sample $\mathrm{C}$, the Ni concentrations in the leachate exceeded the limiting values of the RCMO (Figure 6c). The lowest limit value for $\mathrm{Cu}$ was only exceeded in fraction 11-16 mm of sample C (Figure 6d). 

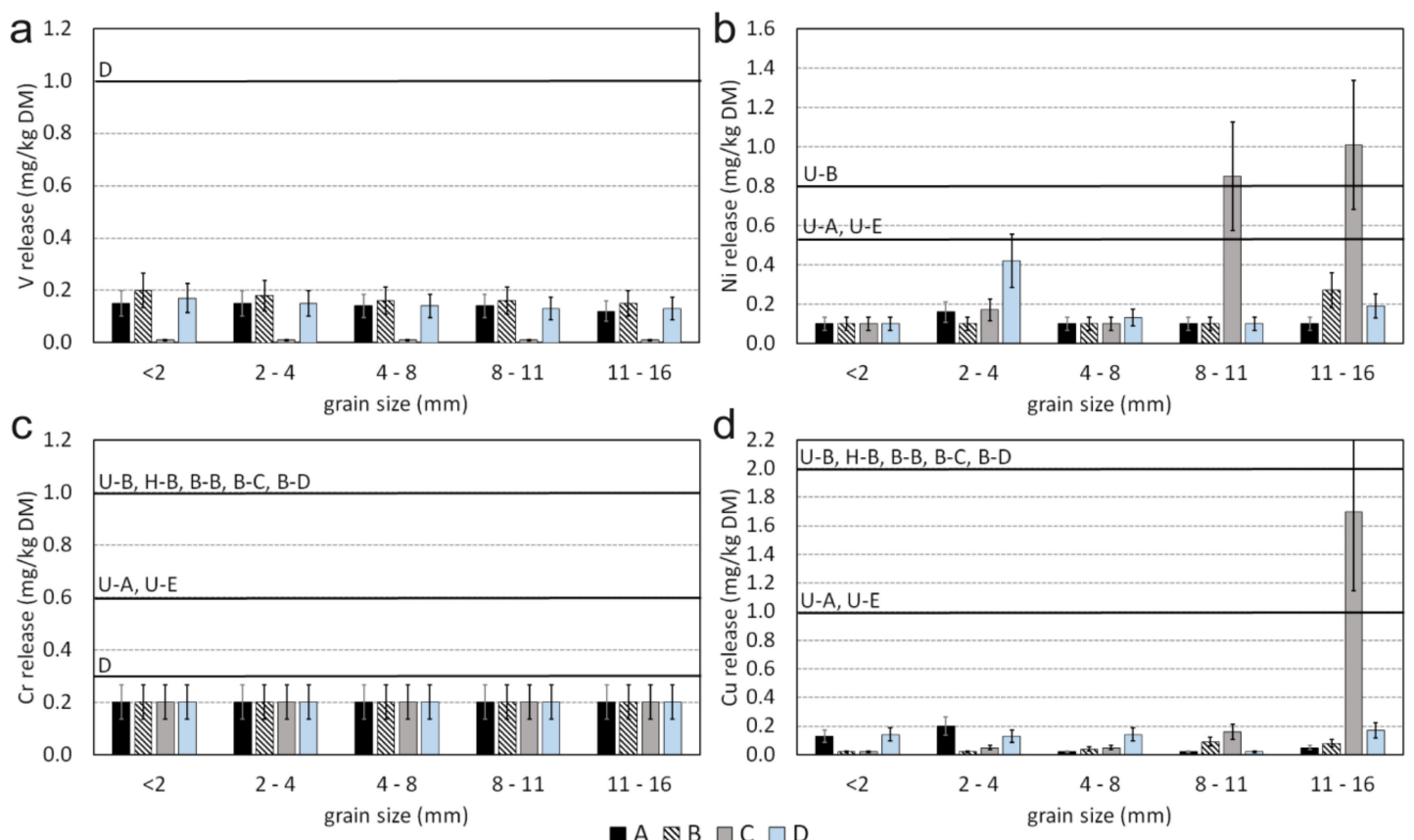

Figure 6. Leachable contents of individual particle size fractions of samples A-D at natural $\mathrm{pH}$ with limit values for different quality classes according to the RCMO: (a) vanadium, (b) nickel, (c) chromium, (d) copper; U-A unbound application, U-B unbound application underneath a low permeable cover layer, U-E unbound application in road construction, $\mathrm{H}-\mathrm{B}$ concrete aggregate, B-B asphalt planings for unbound application, B-C asphalt aggregate, B-D slag-containing asphalt, D slags directly from production.

A comparison of the leachable and total contents shows that Ni not only exceeds limit values for total contents, but also those for the leachable contents in three particle size fractions in two samples. Interestingly, limit values for industrial aggregates (quality classes D and B-D) are partly stricter (e.g., for $\mathrm{Cr}$ ) and partly less strict (e.g., for $\mathrm{Cu}$ ) than for recycled aggregates. The leachable concentrations ( $\left.c_{\text {leachable }}\right)$ do not correlate with the leachable percentage $\left(c_{\text {leachable }} / c_{\text {total }}\right)$. For example, those samples which are characterized by the highest Ni leaching, i.e., the two coarsest fractions of sample C, revealed a lower leachable percentage, i.e., 0.07 and $0.05 \%$ (data not shown), than the sample with the third-highest Ni leaching, i.e., the fraction $2-4 \mathrm{~mm}$ of sample $\mathrm{D}$, from which $0.73 \%$ of the total $\mathrm{Ni}$ was leached. Despite high total concentrations, the concentrations of $\mathrm{Cr}$ in all leachates were below the detection limit of $0.20 \mathrm{mg} / \mathrm{kg}$ DM. The relatively high leaching of $\mathrm{Ni}$ compared to $\mathrm{Cr}$ can be explained with different solubility of the phases incorporating these elements. This is best seen in sample $\mathrm{C}$, the meta-ultramafic rock. There, olivine which is the main carrier of $\mathrm{Ni}$ has a higher solubility compared to Cr-bearing spinel (chromite) which is the dominant $\mathrm{Cr}$ phase (Table S3). This could be explained with the more stable mineralogical bonding of $\mathrm{Cr}$ in the spinel structure than of $\mathrm{Ni}$ which substitutes for $\mathrm{Mg}$ and $\mathrm{Fe}$ in the octahedral sites of the olivine nesosilicate structure. In thermodynamic equilibrium, the phase with the lowest solubility determines the leaching, i.e., the presence of $\mathrm{Cr}$ in other phases (e.g., chlorite) does not yield higher leaching if the phase with the lower solubility can precipitate. It must be noted, however, that chromite was only confirmed in sample $\mathrm{C}$ and it remains unclear which minerals control $\mathrm{Cr}$ leaching in the other samples. Regarding the relatively high leaching of $\mathrm{Cu}$ in one particle size fraction of sample C (Figure 6d), no explanation can be given by the mineralogy as no Cu-bearing phase was observed. However, trace amounts of chalcopyrite as those found in sample B1 cannot be excluded for sample $C$ as well. The leached amounts for all other elements are found in supplementary material Table S6.

The results of the $\mathrm{pH}$ dependence leaching tests are summarized in Figure 7 and Table S7. The data for sample $\mathrm{C}$ show that $\mathrm{Cr}, \mathrm{Ni}$, and $\mathrm{Cu}$ are preferentially leached in the acidic range. Dissolution 
of chromite and silicates releases these metals into the solution. The same is valid for $\mathrm{Cu}$, which can be explained by the weaker sorption of cations to surfaces at an acidic $\mathrm{pH}$ due to their positive surface charge. However, additionally, a slight increase of $\mathrm{Cu}$ leaching is observed for $\mathrm{pH} 13$, possibly because of the release of $\mathrm{Cu}$ due to the dissolution of adsorbing iron hydroxides. In the case of silicate dissolution, $\mathrm{Si}$ and $\mathrm{Al}$ are retained by forming secondary phases like clay minerals. From sample E, between 1 and $6 \mathrm{mg} / \mathrm{kg}$ DM Mo are leached, which is higher than the limit value for, e.g., steel slags in road construction $(0.5 \mathrm{mg} / \mathrm{kg} \mathrm{DM})$, but only about $0.01 \%$ of the total Mo content. As Mo is only bound in molybdenite in this sample, a rather low solubility of this phase can be assumed. The leachable concentrations of all other PEPE are significantly below limit values for sample E.
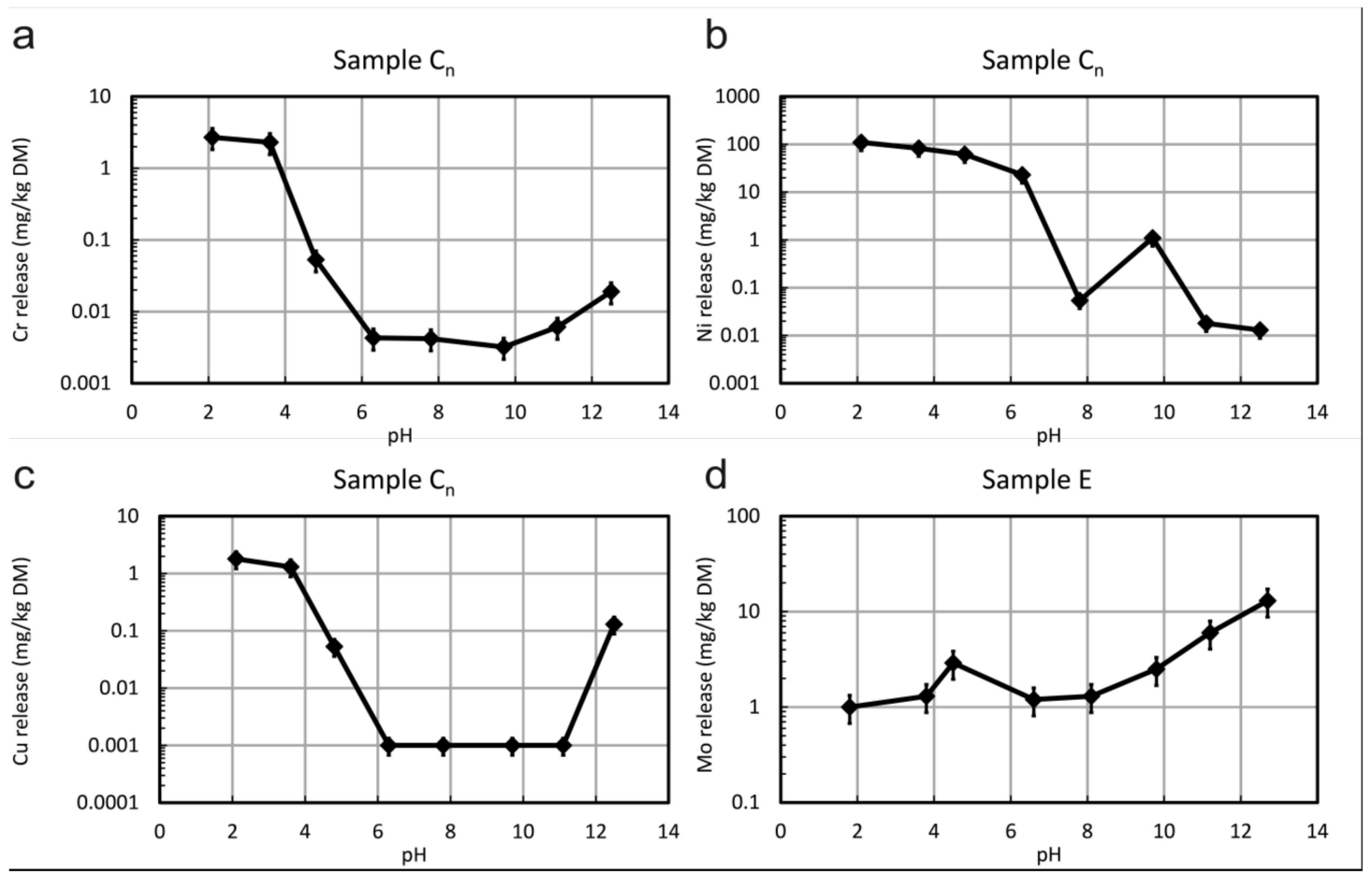

Figure 7. pH-dependent leaching of (a) $\mathrm{Cr}$, (b) $\mathrm{Ni}$, and (c) $\mathrm{Cu}$ from sample $\mathrm{C}_{\mathrm{n}}$ and of (d) Mo from sample E, values refer to the dry matter (DM) of the solid considering a liquid-to-solid ratio of 10:1.

The results of the percolation tests on two samples are presented in Figure 8. During the percolation tests of sample $C_{n}$ (Figure $8 \mathrm{a}, \mathrm{c}$ ), the $\mathrm{pH}$ minimally increased from the first (cumulative $\mathrm{L} / \mathrm{S}=0.1$ ) to the second (cumulative $\mathrm{L} / \mathrm{S}=0.2$ ) fraction and remained stable afterwards. The redox potential increased weakly in the range of 350-400 mV. The electric conductivity decreased continuously from 550 to $250 \mu \mathrm{S} / \mathrm{cm}$ from the first to the fifth fraction analyzed (cumulative $\mathrm{L} / \mathrm{S}=2$ ). Although the obtained leachate fractions are dominated by $\mathrm{Mg}, \mathrm{K}, \mathrm{Fe}, \mathrm{Si}, \mathrm{SO}_{4}$, and $\mathrm{Cl}$, the trend of the conductivity is also reflected in the release of $\mathrm{Cr}$ and $\mathrm{Ni}$. A higher concentration in the second fraction of the percolation test (relative to the first fraction and the following fractions) is usually due to front accumulation and back-mixing [38]. Apart from the second fraction, the concentrations of most elements are rather constant as a function of $\mathrm{L} / \mathrm{S}$, which reveals solubility control.

Percolation tests of sample E (Figure $8 b, \mathrm{~d}$ ) revealed an increase in $\mathrm{pH}$ from 7 to 8.6 and of the redox potential from 270 to $450 \mathrm{mV}$, whereas the electric conductivity decreases from 550 to $200 \mu \mathrm{S} / \mathrm{cm}$ (Figure $8 \mathrm{~b}$ ). The leaching of Mo follows the trend of $\mathrm{Ca}$, which supports the idea that the dissolution of feldspars releases the trace amounts of Mo incorporated therein. 


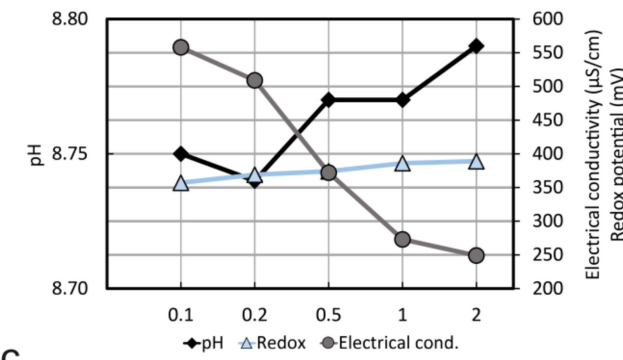

C

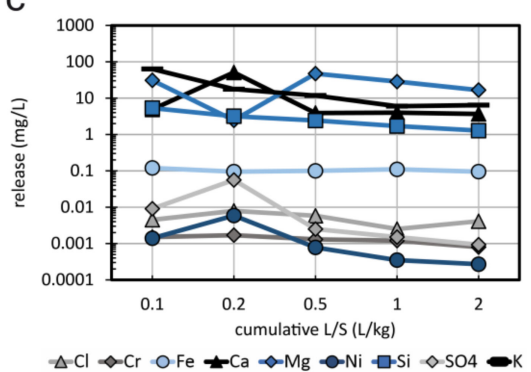

b

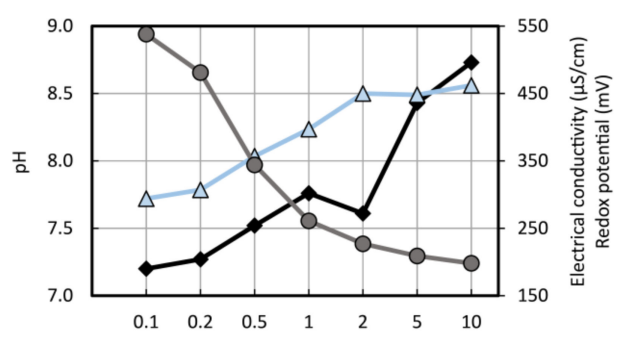

d

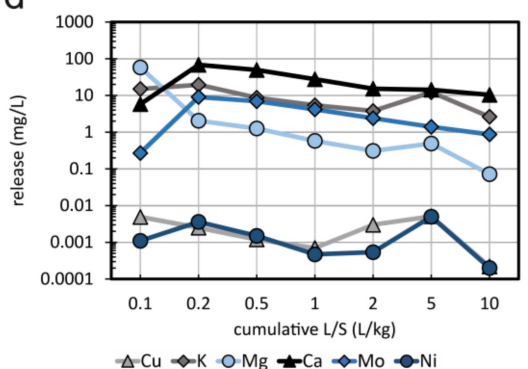

Figure 8. (a) $\mathrm{pH}$, redox potential and electric conductivity during percolation test of sample $\mathrm{C}_{\mathrm{n}}$; (b) $\mathrm{pH}$, redox potential and electric conductivity during percolation test of sample E; (c) concentrations of selected elements in individual fractions during percolation test of sample $C_{n}$; (d) concentrations of selected elements in individual fractions during percolation test of sample E.

\subsection{Hydrogeochemical Modelling}

The results of hydrogeochemical modelling for $\mathrm{Cr}$ and Ni for sample $\mathrm{C}_{\mathrm{n}}$ are presented in Figure 9 . Significant differences between modelled and observed leaching are observed. They may be due to unconsidered substitutions and solid solutions. According to the model, spinel group minerals like chromite dissolve to a very limited degree until equilibrium is reached. This explains the extremely low leaching of $\mathrm{Cr}$. The presence of spinels is in agreement with mineralogical observation. If the $\mathrm{pH}$ decreases below 9, the model suggests that the solubility of spinel increases but a part of the released $\mathrm{Cr}$ will be adsorbed onto HFO which were postulated to be present in the model. However, HFO were not identified in mineralogical investigations. The leaching of $\mathrm{Ni}$ is underestimated by the model, especially between $\mathrm{pH} 9$ and 11. Here, the model suggests that the Ni-bearing olivine dissolves until equilibrium is reached. Ni-bearing olivine was also found by EPMA. The subsequent precipitation of Ni-bearing phyllosilicates, which is observed in garnierite deposits [39], is not suggested by the model. An explanation for this deviation may be the leaching of Ni from another, more soluble mineral phase. According to EPMA, serpentine, chlorite, and tremolite, might be such phases, but Ni substitution into them was not considered in the model. However, as the model suggests subsequent adsorption of $\mathrm{Ni}$ onto HFO, this process would need to be suppressed to explain the higher Ni leaching in experiments. 

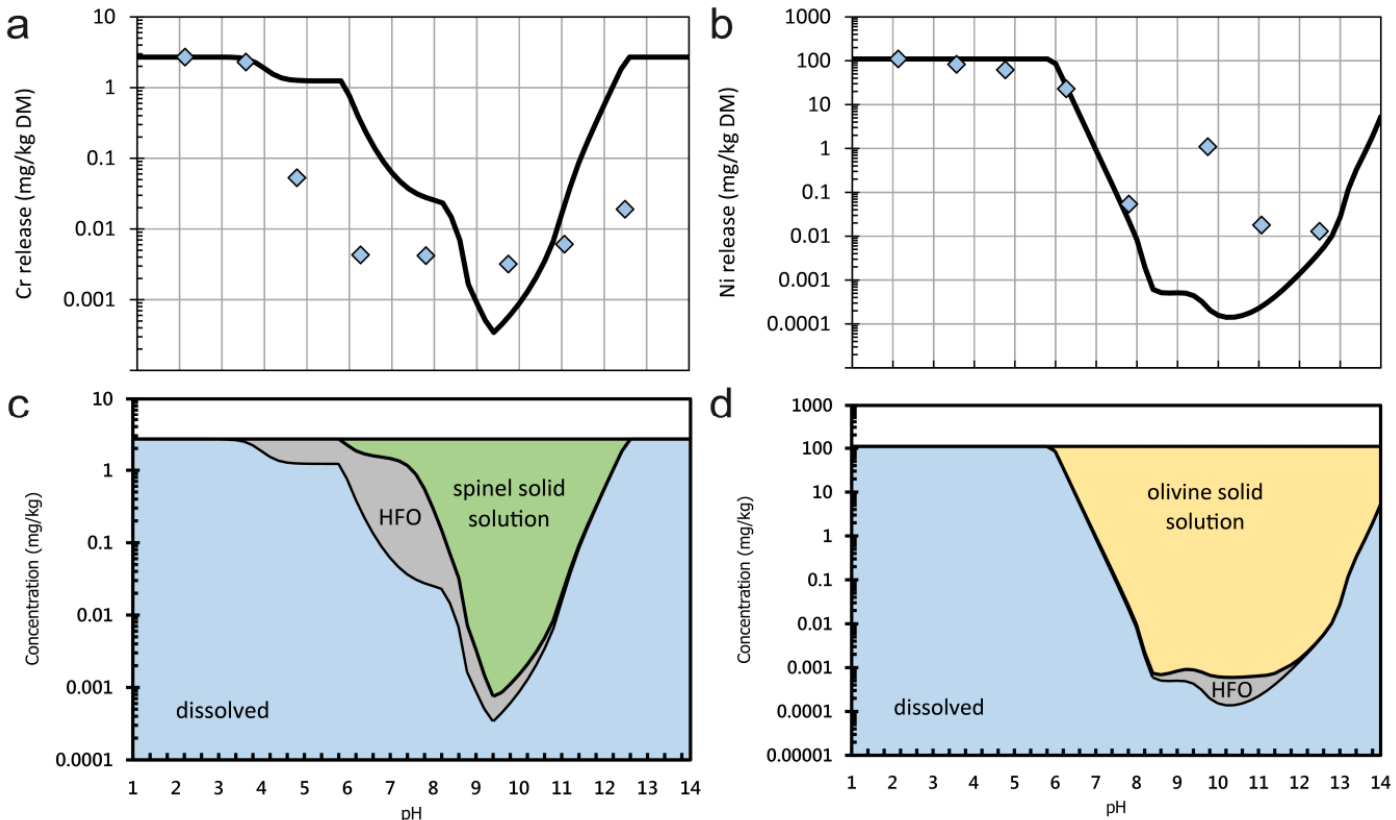

Figure 9. (a) Concentration of $\mathrm{Cr}$ in solution as a function of $\mathrm{pH}$ for sample $\mathrm{C}_{n}$; (b) concentration of $\mathrm{Ni}$ in solution as a function of $\mathrm{pH}$ for sample $\mathrm{C}_{n}$; (c) phases which are suggested to control the leachability of $\mathrm{Cr}$ in sample $\mathrm{C}_{\mathrm{n}}$ by precipitation/dissolution or adsorption/desorption equilibria. HFO: hydrous ferric oxides; (d) phases which are suggested to control the leachability of $\mathrm{Ni}$ in sample $\mathrm{C}_{\mathrm{n}}$ by precipitation/dissolution or adsorption/desorption equilibria. Symbols indicate measured and lines and modelled dissolved concentrations.

Hydrogeochemical modelling of sample E (Figure 10) could not predict the leaching of Mo well. Considering molybdenite for the calculations, which is the main Mo-bearing phase in the sample, underestimated the observed leaching. This suggests that a small fraction of Mo exists in higher soluble phases. According to hydrogeochemical modelling results, wulfenite $\left(\mathrm{PbMoO}_{4}\right)$ might be such a phase after the exclusion of molybdenite from the model. This is supported by the fact that this phase was found as an accessory phase in the same material in another study [35]. Considering the low total $\mathrm{Pb}$ content of $13 \mathrm{mg} / \mathrm{kg} \mathrm{DM}$, this phase could only occur in traces. However, this would be sufficient to yield the observed leachable Mo contents of 1 to $6 \mathrm{mg} / \mathrm{kg}$ DM. It also needs to be mentioned that the total content of $\mathrm{Pb}$ leaches at both $\mathrm{pH} 1.8$ and $\mathrm{pH} 12.7$. However, much lower leaching $(<0.1 \mathrm{mg} / \mathrm{kg}$ $\mathrm{DM}$ ) occurs at a moderate $\mathrm{pH}$. This is in agreement with the solubility curve of wulfenite (Figure 10). Adsorption onto HFO, on the other hand, which is also suggested by hydrogeochemical modelling, would underestimate Mo leaching. Another possible explanation for Mo leaching is the release from feldspars in which trace amounts of Mo may substitute for Al [40]. Indeed, EPMA results suggest that Mo concentrations in the range of the detection limit occur in feldspars, but also in muscovite. However, in the model, this substitution is not considered although the solubility of feldspars under acidic conditions suggests that Mo should be at least partly available in this case. 

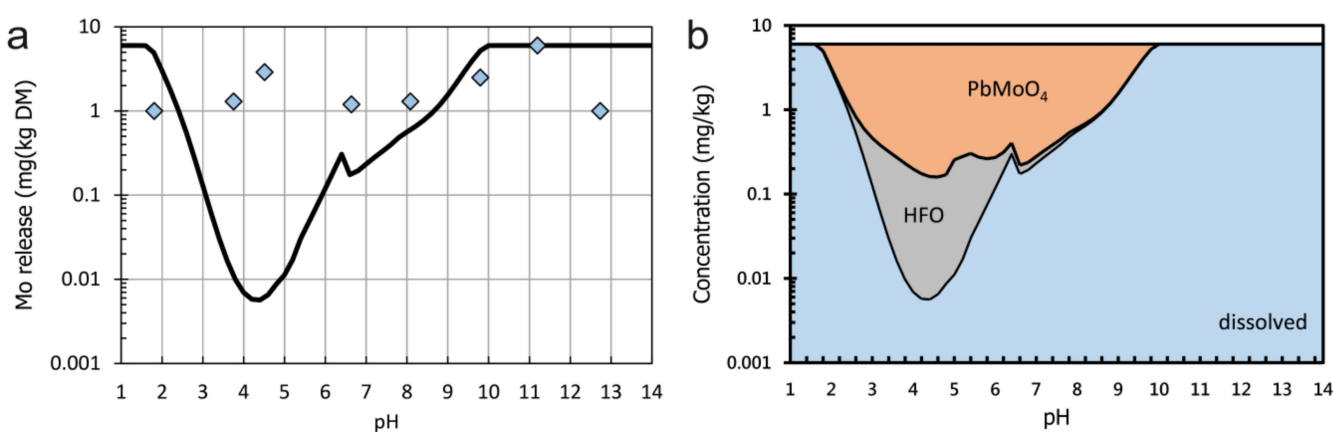

Figure 10. Concentration of Mo in solution as a function of $\mathrm{pH}$ for sample E. (a) Measured (symbols) and modelled (black line) dissolved concentrations; (b) phases which are suggested to control the leachability of by precipitation/dissolution or adsorption/desorption equilibria, resulting in the modelled curve in the left diagram.

\section{Discussion}

Natural rocks compete with secondary raw materials, e.g., steel slags or construction and demolition (C and D) waste, for an application as an aggregate for concrete or asphalt or as a base layer in road construction. As this study was conducted within a research project focussing on EAF slag, the investigated rocks, i.e., potential natural aggregates, are compared with EAF slags but also other types of slags, i.e., industrial aggregates.

In comparison with EAF slags, all the observed rock samples are characterized by lower $\mathrm{Cr}$ and $\mathrm{V}$ contents [41] and in the case of sample $\mathrm{C}$ also by significantly higher $\mathrm{Ni}$ contents [42]. Spinels play an important role as host phases for $\mathrm{Cr}$, both in the investigated rock sample $\mathrm{C}$ and in EAF slag [41]. Olivine, which is a host phase for $\mathrm{Ni}$ in sample $\mathrm{C}$, was also found in EAF slag as a host phase for $\mathrm{V}$. Titanite, which was identified as the main $\mathrm{V}$ carrier in samples $\mathrm{B}$ and $\mathrm{D}$, has also been found in basic oxygen furnace (BOF) slag [43]. Melilite $\left((\mathrm{Ca}, \mathrm{Na})_{2}\left(\mathrm{Mg}, \mathrm{Al}^{2}\left[\mathrm{Si}_{2} \mathrm{O}_{7}\right]\right)\right.$, whose hydration products were suggested to secondarily fix $\mathrm{V}$ in EAF slag (unpublished data), was not found in natural rock samples. Contrarily, molybdenite, which is the main Mo phase in sample E, has not been found in EAF slags, which are furthermore characterized by much lower Mo and S contents. Comparison of the leachable concentrations at natural $\mathrm{pH}$ of the investigated rock samples with that of EAF slags [44] shows higher $\mathrm{Ni}$ leaching for sample $\mathrm{C}$ whereas leaching of $\mathrm{V}$ and $\mathrm{Cr}$ is in the same extremely low range for both types of materials. A comparison of the modelled leaching controlling mechanisms [45] shows that the same processes, i.e., incorporation into spinels and adsorption onto iron hydroxides, control the leaching of chromium. In contrast, neither for the natural rock sample E nor for the EAF slag (unpublished data) was a well-fitting control mechanism for the leaching of Mo found. Further research is needed to better explain the leaching of Mo from both natural and industrial aggregates.

In summary, the leachability of PEPE in natural and industrial aggregates, is controlled by similar mineralogical mechanisms, e.g., the stable incorporation of $\mathrm{Cr}$ in spinels. No general statement for which material group (natural or industrial aggregate) releases less PEPE into the environment can be made, as specific materials and their mineralogy as well as the hydrogeochemical framework conditions, e.g., $\mathrm{pH}$ and Eh, have to be considered.

\section{Conclusions}

Based upon the new data presented here and comparison with existing data as discussed above, the following conclusions can be drawn:

(1) Five rocks-four of them are quarried in Austria for commercial purposes-have been investigated regarding the leachability of potentially environmentally problematic elements (PEPE: $\mathrm{Cr}, \mathrm{Ni}$, $\mathrm{V}$, and Mo etc.) depending on mineralogy. The motivation of this study was to get data for the 
comparison with synthetic materials (slags, recycled materials etc.) which can be used in similar commercial applications but for which limit values are defined in national regulations.

(2) Only two samples have considerable higher total concentrations of Ni and Cr. Sample C, a meta-ultramafic rock ("serpentinite"), has up to $1033 \mathrm{mg} / \mathrm{kg} \mathrm{Cr}$ which is bound in chromite and subordinately in silicates (chlorite). Higher Ni contents in the same sample are bound to olivine.

(3) It is demonstrated that $\mathrm{Cr}$ leaching is very low which can be explained by the very low solubility of chromite; in contrast the leaching of $\mathrm{Ni}$ is higher which can be explained with the higher solubility of $\mathrm{Ni}$ in olivine and/or other Ni phases.

(4) Sample E, a molybdenite-bearing orthogneiss from the Hohe Tauern area, contains up to $49,500 \mathrm{mg} / \mathrm{kg} \mathrm{Mo}$, which is bound to molybdenite. This mineralized rock is not used as a construction material but was included in order to investigate the behaviour of Mo during leaching processes. Only small amounts of Mo $(<6 \mathrm{mg} / \mathrm{kg})$ are leached but the solubility of molybenite is modelled to be even lower. Thus the leaching of Mo must be controlled by other phases. Feldspars containing traces of Mo or secondary minerals like wulfenite could be alternative sources of Mo.

Supplementary Materials: The following are available online at http://www.mdpi.com/2075-163X/9/8/501/s1, Table S1: PEPE their concentration ranges in rocks and their mineral phases (data from [5], if not indicated differently) [46-48], Table S2: Measurement conditions for EPMA analyses, Table S3: Mineral phases containing $\mathrm{Cr}, \mathrm{Cu}$ and $\mathrm{Ni}$ (for sample $\mathrm{C}_{\mathrm{n}}$ ) and $\mathrm{Mo}$ (for sample $\mathrm{E}$ ) and their formation reaction used for hydrogeochemical modelling (Mineral names according to the databases, ss: solid solution) [49], Table S4: EPMA of titanite grains (14 spots) in sample B1 (bdl = below detection limit), Table S5: EPMA (average values) of silicate phases in sample $\mathrm{C}$ (bdl = below detection limit), Table S6: Leachable contents of chemical elements of the investigated samples at natural $\mathrm{pH}$ (A: quaternary gravel, B: diabase greywacke mixture, C: serpentinite and D: amphibolite breccia; terminology is according to the supplier and not according to scientific rock classification; bold script indicates elements whose leachable contents are regulated in Austrian legislation, red letters indicate values exceeding a limit value, all results are in $\mathrm{mg} / \mathrm{kg}$ and refer to the dry matter of the solid, considering a solid-to-liquid ratio of 1:10). The estimated extended measurement uncertainty according to the EURACHEM/CITAC guideline is in the range of 30 to $35 \%$ for most elements, Table S7: Leachable contents of chemical elements of the investigated samples at varying $\mathrm{pH}$ (C: serpentinite, E: Mo-bearing gnesiss; bold script indicates elements whose leachable contents are regulated in Austrian legislation, all results are in $\mathrm{mg} / \mathrm{kg}$ and refer to the dry matter of the solid, considering a solid-to-liquid ratio of 1:10, bdl: below detection limit). The estimated extended measurement uncertainty according to the EURACHEM/CITAC guideline is in the range of 30 to $35 \%$ for most elements.

Author Contributions: Conceptualization, D.V.; methodology, D.V., S.N. and J.G.R.; software, J.J.D. and A.v.Z.; investigation, I.A.-J., S.N. and M.B.; resources, A.A., and J.G.R.; data curation, J.G.R. and A.A.; writing-original draft preparation, D.V.; writing-review and editing, S.N., K.P.S., J.J.D., A.v.Z., and J.G.R.; visualization, S.N. and K.P.S.; supervision, J.G.R. and D.V.; project administration, S.N. and D.V.; funding acquisition, D.V.

Funding: This research was conducted within the project MiLeSlag (Mineralogy and Leachability of Steel Slags) which was funded by the Austrian Research Promotion Agency (FFG) within the program "Bridge Early Stage", grant number 851210 .

Acknowledgments: The authors thank Federica Zaccarini for assistance with EPMA and Maik Zimmermann for the sample preparation.

Conflicts of Interest: The authors declare no conflict of interest.

\section{References}

1. Baurohstoffe. Available online: https://www.bmnt.gv.at/energie-bergbau/bergbau/mineralische-rohstoffe/ Baurohstoffe.html (accessed on 25 February 2019).

2. Material Flow Accounts. Non-Metallic Minerals, Domestic Material Consumption. Available online: http://appsso.eurostat.ec.europa.eu/nui/submitViewTableAction.do (accessed on 4 June 2019).

3. Austrian Standards. ÖNORM B 3130: 201608 01. Gesteinskörnungen für Asphalte und Oberflächenbehandlungen für Straßen, Flugplätze und andere Verkehrsflächen-Regeln zur Umsetzung der ÖNORM EN 13043; Austrian Standards International: Vienna, Austria, 2016.

4. Federal Ministry for Agriculture and Forestry, Environment and Waste Management. Recycling Baustoffverordnung. Available online: https://www.ris.bka.gv.at/GeltendeFassung.wxe?Abfrage= Bundesnormen\&Gesetzesnummer=20009212 (accessed on 19 August 2019). 
5. Thalmann, F.; Schermann, O.; Schroll, E.; Hausberger, G. Geochemical Atlas of the Republic of Austria 1:1,000.000; Geological Survey of Austria: Vienna, Austria, 1989.

6. Pohl, W. Economic Geology Principles and Practice-Metals, Minerals, Coal and Hydrocarbons-Introduction to Formation and Sustainable Exploitation of Mineral Deposits; Blackwell Publishing Ltd.: Hoboken, NJ, USA, 2001.

7. Edgar, A.; Pizzolato, L.; Sheen, J. Flourine in igeneous rocks and minerals with emphasis on ultrapotassic mafic and ultramafic magmas and their mantle source regions. Miner. Mag. 1996, 60, 243-257. [CrossRef]

8. European Committee for Standardization (CEN). DIN EN 1744-3. Tests for Chemical Properties of Aggregates-Part 3: Preparation of Eluates by Leaching of Aggregates; Beuth Verlag GmbH: Berlin, Germany, 2002.

9. Deutsches Institut für Normung. DIN 19529:2015-12. Leaching of Solid Materials-Batch Test for the Examination of the Leaching Behaviour of Inorganic and Organic Substances at a Liquid to Solid Ratio of 2 l/kg; Beuth Verlag GmbH: Berlin, Germany, 2015.

10. European Committee for Standardization (CEN). DIN EN 12457. Characterization of Waste-Leaching; Compliance Test for Leaching of Granular and Sludges; Beuth Verlag GmbH: Berlin, Germany, 2003.

11. European Committee for Standardization (CEN). DIN EN 14405. Characterization of Waste-Leaching Behaviour Test-Up-Flow Percolation Test (Under Specified Conditions); Beuth Verlag GmbH: Berlin, Germany, 2017.

12. Deutsches Institut für Normung. DIN 19528. Leaching of Solid Materials-Percolation Method for the Joint Examination of the Leaching Behaviour of Inorganic and Organic Substances; Beuth Verlag GmbH: Berlin, Germany, 2009.

13. European Committee for Standardization. DIN EN 14429. Characterization of Waste-Leaching Behaviour Test-Influence of ph on Leaching with Initial Acid/Base Addition; Beuth Verlag GmbH: Berlin, Germany, 2015.

14. Potysz, A.; van Hullebusch, E.; Kierczak, J. Perspectives regarding the use of metallurgical slags as secondary metal resources-A review of bioleaching approaches. J. Environ. Manag. 2018, 219, 138-152. [CrossRef] [PubMed]

15. Forschungsgesellschaft für Straßen- und Verkehrswesen (FGSV). Technische Lieferbedingungen für Gesteinskörnungen im Straßenbau: TL Gestein-Stb 04, Köln; FGSV-Verlag: Cologne, Germany, 2008.

16. Van Houdt, J.; Wolf, E.; Duzijn, R. Composition and leaching characteristics of road construction materials. In Waste Materials in Construction, Proceedings of the International Conference on Environmental Implications of Construction with Waste Materials, Maastricht, The Netherlands, 10-14 November 1991; Elsevier: New York, NY, USA.

17. Tossavainen, M.; Forssberg, E. The potential leachability from natural road construction materials. Sci. Total Env. 1999, 239, 31-47. [CrossRef]

18. Rivera, J.; Reich, M.; Schoenberg, R.; González-Jiménez, J.; Barra, F.; Aiglsperger, T.; Proenza, J.; Carretier, S. Platinum-group element and gold enrichment in soils monitored by chromium stable isotopes during weathering of ultramafic rocks. Chem. Geol. 2018, 499, 84-99. [CrossRef]

19. Ratié, G.; Jouvin, D.; Garnier, J.; Rouxel, O.; Miska, S.; Guimaraes, E.; Cruz Viera, L.; Sivry, Y.; Zelano, I.; Montarges-Pelletier, E.; et al. Nickel isotope fractionation during tropical weathering of ultramafic rocks. Chem. Geol. 2015, 402, 68-76. [CrossRef]

20. Wang, Z.; Ma, J.; Li, J.; Wei, G.; Zeng, T.; Li, L.; Zhang, L.; Deng, W.; Xie, L.; Liu, Z. Fe (hydro)oxide controls Mo isotope fractionation during the weathering of granite. Geochim. Cosmochim. Acta 2018, 22, 1-17. [CrossRef]

21. European Committee for Standardization (CEN). DIN EN 13656. Characterization of Waste-Microwave Assisted Digestion with Hydrofluoric ( $\mathrm{HF})$, Nitric $\left(\mathrm{HNO}_{3}\right)$ and Hydrochloric $(\mathrm{HCl})$ acid Mixture for Subsequent Determination of Elements in Waste; Beuth Verlag GmbH: Berlin, Germany, 2002.

22. European Committee for Standardization (CEN). DIN EN ISO 17294-2. Water Quality-Application of Inductively Coupled Plasma Mass Spectrometry (ICP-MS)_Part 2: Determination of 62 Elements; Beuth Verlag GmbH: Berlin, Germany, 2017.

23. European Committee for Standardization (CEN). DIN EN ISO 11885. Water Quality—Determination of Selected Elements by Inductively Coupled Plasma Optical Emission Spectrometry (ICP-OES); Beuth Verlag GmbH: Berlin, Germany, 2007.

24. European Committee for Standardization. EN ISO 10304-1. Water Quality-Determination of Dissolved Anions by Liquid Chromatography of Ions-Part 1: Determination of Bromide, Chloride, Fluoride, Nitrate, Nitrite, Phosphate and Sulfate; Beuth Verlag GmbH: Berlin, Germany, 2009. 
25. Deutsches Institut für Normung (DIN). DIN 38405-24. German Standard Methods for the Examination of Water, Waste Water and Sludge; Anions (group D); Photometric Determination of Chromium(VI) Using 1,5-Diphenylcarbonohydrazide (D 24); Beuth Verlag GmbH: Berlin, Germany, 1987.

26. European Committee on Standardization (CEN). DIN EN 1484. Water Analysis—Guidelines for the Determination of Total Organic Carbon (TOC) and Dissolved Organic Carbon (DOC); Beuth Verlag GmbH: Berlin, Germany, 1997.

27. Meeussen, J. ORCHESTRA: An object-oriented framework for implementing chemical equilibrium models. Env. Sci. Technol. 2003, 37, 1175-1182. [CrossRef] [PubMed]

28. US-EPA. National Exposure Research Laboratory, Ecosystems Research Division. In MINTEQA2/PRODEFA2, A Geochemcial Assessment Model for Environmental Systems: User Manual Supplement for Version 4.0; HydroGeoLogic, Inc.: Herndon, VA, USA, 1999.

29. Delany, J.; Lundeen, S. The LNLL Thermodynamic Database; Lawrence Livermore National Laboratory: Livermore, CA, USA, 1990.

30. Blanc, P.; Lassin, A.; Piantone, P.; Azaroual, M.; Jacquemet, N.; Fabbri, A.; Gaucher, E.C. Thermoddem: A geochemical database focused on low temperature water/rock interactions and waste materials. Appl. Geochem. 2012, 27, 2107-2116. [CrossRef]

31. Loncnar, M.; van der Sloot, H.; Mladenovič, M.; Zupančič, L.; Kobal, L.; Bukovec, P. Study of the leaching behaviour of ladle slags by means of leaching tests combined with geochemical modelling and mineralogical investigations. J. Hazard. Mater. 2016, 317, 147-157. [CrossRef] [PubMed]

32. Rudnick, R.; Gao, S. Composition of the continental crust. In Treatise on Geochemistry, 3rd ed.; Elsevier-Pergamon: Amsterdam, The Netherlands, 2003; pp. 1-64.

33. Pan, Y.; Fleet, M. Mineral chemistry and geochemistry of vanadian silicates in the Hemlo gold deposit, Ontario, Canada. Contrib. Mineral. Petr. 1992, 109, 511-525. [CrossRef]

34. Dalou, C.; Koga, K.; Shimzu, N.; Boulon, J.; Devidal, J. Experimental determination of F and Cl partitioning between lherzolite and basaltic melt. Contrib. Mineral. Petr. 2012, 163, 591-609. [CrossRef]

35. Steiner, T. Aplite hosted Reichenspitz-type molybdenite molybdenite mineralization in the Central Tauern Window, Salzburg/Tyrol. Master Thesis, Montanuniversität Leoben, Leoben, Styria, Austria, 2018.

36. Greaney, A.; Rudnick, N.; Gaschnig, R.; Wahlen, J.; Luais, B.; Clemens, J. Geochemistry of molybdenum in the continental crust. Geochim. Cosmochim. Acta 2018, 238, 36-54. [CrossRef]

37. Dijkstra, J.; van der Sloot, H.; Comans, R. The leaching of major and trace elements from MSWI bottom ash as a function of $\mathrm{pH}$ and time. Appl. Geochem. 2006, 21, 335-351. [CrossRef]

38. Dijkstra, J.; Meeussen, J.; van der Sloot, H.; Comans, R. A consistent geochemical modelling approach for the leaching and reactive transport of major and trace elements in MSWI bottom ash. Appl. Geochem. 2008, 23, 1544-1562. [CrossRef]

39. Villanova-de-Benavent, C.; Proenza, J.A.; Galí, S.; García-Casco, A.; Tauler, E.; Lewis, J.F.; Longo, F. Garnierites and garnierites: Textures, mineralogy and geochemistry of garnierites in the Falcondo Ni-laterite deposit. Ore. Geol. Rev. 2014, 59, 91-109. [CrossRef]

40. Arnórsson, S.; Óskarsson, N. Molybdenum and tungsten in volcanic rocks and in surface and $<100{ }^{\circ} \mathrm{C}$ ground waters in Iceland. Geochim. Cosmochim. Acta 2007, 71, 284-304.

41. Neuhold, S.; Vollprecht, D.; Berger, M.; Raith, J.G.; Schüler, S.; Mudersbach, D. Auslaugverhalten von Stahlwerksschlacken und natürlichen Gesteinen-Ein Vergleich. In Schlacken-Symposium der Max Aicher Unternehmensgruppe; Max Aicher Unternehmensgruppe: Meitingen, Germany, 2018; pp. 179-189.

42. Proctor, D.; Fehling, K.; Shay, E.; Wittenborn, J.; Green, J.; Avent, C.; Bigham, R.; Connolly, M.; Lee, B.; Shepker, T.; et al. Physical and chemical characteristics of blast furnace, basic oxygen furnace and electric arc furnace steel industry slags. Environ. Sci. Technol. 2000, 34, 1576-1582. [CrossRef]

43. Wu, X.; Wang, P.; Li, L.; Wu, Z.; Chen, R. Distribution and enrichment of phosphorous in solidified BOF steelmaking slag. Ironmak. Steelmak. 2011, 38, 185-188. [CrossRef]

44. Aldrian, A.; Raith, J.G.; Höllen, D.; Pomberger, R. Influence of chormium containing spinels in electric arc furnace slag on the leaching behaviour. J. Solid Waste Technol. Manag. 2015, 41, 357-365. [CrossRef]

45. Höllen, D.; Neuhold, S.; Mudersbach, D.; Schüler, S.; Sommerauer, H.; Griessacher, T.; Dijkstra, J.; van Zomeren, A.; Presoly, P.; Schenk, J.; et al. Möglichkeiten und Grenzen von Modellen zur Vorhersage der Auslaugbarkeit von Stahlwerksschlacken. In Proceedings of the Mineralische Nebenprodukte und Abfälle, Berlin, Germany, 12-13 June 2017; TK Verlag: Neuruppin, Germany, 2017; pp. 205-222. 
46. Deer, W.; Howie, R.; Zussman, J. An Introduction to the Rock-Forming Minerals; The Mineralogical Society: Twickenham, UK, 2013.

47. Okrusch, M.; Matthes, S. Mineralogie: Eine Einführung in die spezielle Mineralogie, Petrologie und Lagerstättenkunde, 8th ed.; Springer: Berlin/Heidelberg, Germany, 2013.

48. Thalhammer, O.; Ebner, F.; Horkel, K.; Mali, H. Der Ultramafit-Komplex von Kraubath. In Proceedings of the PANGEO 2010, Leoben, Austria, 15-19 September 2010.

49. Kindness, A.; Lachowski, E.; Minocha, A.; Glasser, F. Immobilisation and fixation of molybdenum(VI) by Portland cement. Waste Manag. 1994, 14, 97-102. [CrossRef] 